\title{
Half-Century Changes in LULC and Fire in Two Iberian Inner Mountain Areas
}

\author{
Catarina Romão Sequeira ${ }^{1, *(\mathbb{C})}$, Francisco Castro Rego ${ }^{2}$, Cristina Montiel-Molina ${ }^{1}$ and \\ Penelope Morgan ${ }^{3}$ \\ 1 Department of Geography, Complutense University of Madrid, 28040 Madrid, Spain \\ 2 Centro de Ecologia Aplicada Prof. Baeta Neves, University of Lisbon, 1649-004 Lisboa, Portugal \\ 3 Department of Forest, Rangeland, and Fire Sciences, University of Idaho, Moscow, ID 83844, USA \\ * Correspondence: anacatte@ucm.es; Tel.: (+34)-91-394-5292
}

Received: 22 May 2019; Accepted: 2 August 2019; Published: 8 August 2019

\begin{abstract}
Wildfires in the Iberian Peninsula were large and frequent in the second half of the 20th century. Land use and land cover (LULC) also changed greatly. Our aim was to understand the relationship between LULC and fire in the western and eastern ends of the Iberian Central Mountain System. We compared two case study landscapes, the Estrela massif and the Ayllón massif, which are biophysically similar but with different social-ecological contexts. In both, fires were in general more likely in shrublands and pastures than in forests. Shrublands replaced forests after fires. Contrasting LULC in the two massifs, particularly pastures, likely explained the differences in fire occurrence, and reflected different regional land use policies and history. Fire here is a social-ecological system, influenced by specific LULC and with implications from landscape to regional scales. Understanding how LULC changes interact with fire is powerful for improving landscape and regional planning.
\end{abstract}

Keywords: Ayllón massif; Estrela massif; fire; Iberian Peninsula; landscape dynamics; landscape scale; rural mountain areas; wildfires

\section{Introduction}

Land use and land cover (LULC) in the Iberian Peninsula have undergone substantial changes through the second half of the 20th century, mostly related to human activities resulting from economic development [1]. Such LULC changes have triggered a change in the fire patterns in this territory [2-4]. However, the influence of the social context on the interaction between fire and LULC is poorly understood yet critical to effective planning and policy.

The Central Mountain System of the Iberian Peninsula is a good example of the regional, national and global social-ecological dynamics that happened in the second half of the 20th century [5-9]. This area is historically very fire prone $[10,11]$, and the interactions between LULC and fire have been studied at the regional and landscape scales (e.g., [10,12-14]). Nevertheless, less attention has been paid to the two ends of that region [15] from a comparative perspective. Although they belong to the same mountain system and are therefore biophysically similar, they are in two different countries. Is the difference between the two fire frequencies due to the different social-political contexts? Analysis of LULC changes in the Estrela massif (the western end of the Central Mountain System situated in Portugal) showed that since $1000 \mathrm{yr}$ BP there was a general deforestation (i.e., conversion of forest land to non-forest land, or decrease in tree canopy cover) of the upper elevations of the massif while Pinus forest area increased at lower elevations because of excessive grazing [16]. The currently forested landscape is a result of the reforestations (i.e., conversion of non-forested lands to forests, or increase in tree canopy cover), mostly with Pinus, that took place after the establishment of the Portuguese national forests in the late 19th century [17-19]. The Estrela massif is characterized by large burned 
areas despite relatively few ignitions when compared to the Portuguese national numbers [20-22], and fire selectivity studies (e.g., [23]) confirmed the LULC relationship with fire. In contrast, at the eastern end of the Central Mountain System, in the Ayllón massif in Spain, LULC investigations showed that once extensive forest area (ca. 4000-2000 yr. BP) decreased with the intensification of human activities [24,25], and that the Spanish Forest Administration carried out several reforestations over the 20th century for hydrological-woodland restoration and erosion control in the upper parts of the watersheds [26]. Fire in the Ayllón massif is characterized by very few ignitions and large burned areas [27]. However, the Estrela massif has a much higher fire frequency than the Ayllón massif from the late 20th century.

Fire dynamics were not simple. In both Spain and Portugal, an abrupt change in the fire regime (number of fires, as well as in the burned area) occurred in the 1970s and again in the 1990s [28-31]. The landscape structure and pattern are influenced by fires [2,13,32-36]. Fires burned LULC types disproportionally to their abundance but fire selectivity was weaker as fire size increased [37-40]. Although the likelihood of burning was high in shrubland and forest areas in Spain [41,42] and in Portugal [43], fire density was not found to be related to LULC in Spain and in Portugal [39,44-46]. Besides shrubland, Pinus forests were the most fire prone, in contrast to agricultural-related LULC [22,23,34,37,38,47,48]. Given these findings, many researchers called for local and landscape approaches to identify and explain the drivers of landscape and fire variations [49-51], as they are changing over time [52]. This could inform regional land use and fire policies.

In this paper we assess the interaction between burned areas and LULC (including forest composition) in the second half of the 20th century in the Estrela and Ayllón massifs, during the period of the abrupt change in the fire regime found in both countries in the 1970s and in the 1990s. We used mathematical transition matrices and fire selectivity indexes, which have been widely used in this context and have proved to be suitable (e.g., [40,53-55]). We are interested in understanding if the LULC and fire interactions could explain the much more extensive fires in Estrela, or if it is because the Estrela and Ayllón massifs are situated in two different countries. Comparing these biophysically similar areas enables us to understand how their landscape organization and dynamics likely influence and are influenced by fire, and how this could be shaped by their different social history and context. Our hypotheses are that, regardless of the contrasting fire frequencies in the two areas, (1) fire affected LULC transitions, and that (2) LULC influenced fire selectivity, i.e., different LULC categories had different fire proneness in both the Estrela and Ayllón massifs. Assessing the interplay between fire and LULC transitions at the landscape scale within two different social-ecological contexts is important to developing smarter fire and landscape management strategies for reducing risk and damages from fire. Also, the approach taken in this study allows for a better understanding of the processes by addressing separately the relationship between fire and LULC transitions and then how LULC affects fire.

\section{Methodology}

\subsection{Study Area}

We investigated two areas at the eastern and western ends of the Central Mountain System of the Iberian Peninsula. Both are representative of regional environment features and have a long history of fire. As these inner Iberian Peninsula Mountain areas belong to different countries, they are subject to contrasting national forest and regional development policies.

Administrative boundaries: The Estrela massif case study area, located in Portugal, covers about 58 thousand hectares, and includes five administrative municipalities of two Districts (Guarda and Castelo Branco). The Ayllón massif case study area, located in Spain, covers about 63 thousand hectares, and includes seven municipalities of the Guadalajara District (Figure 1). 


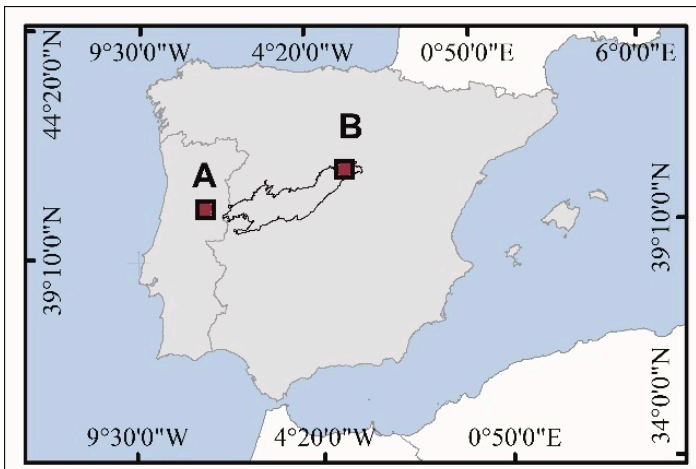

A: Estrela massif case study

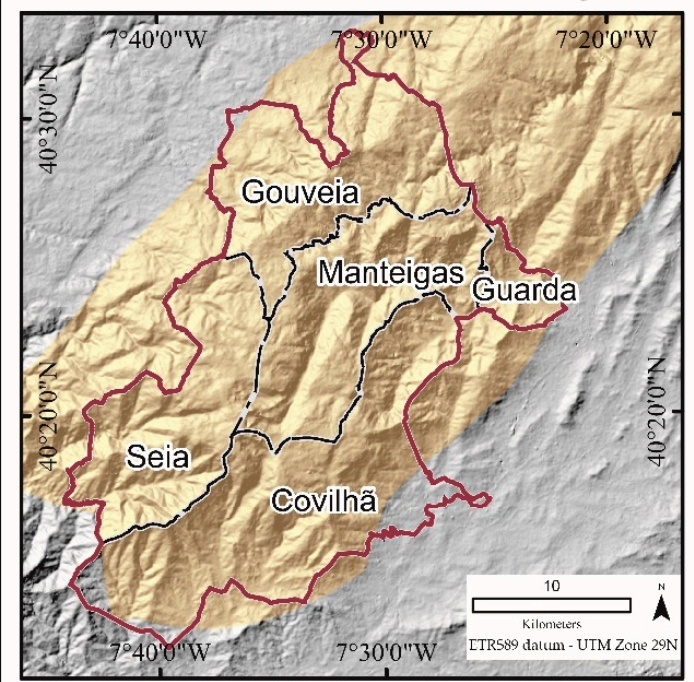

B: Ayllón massif case study

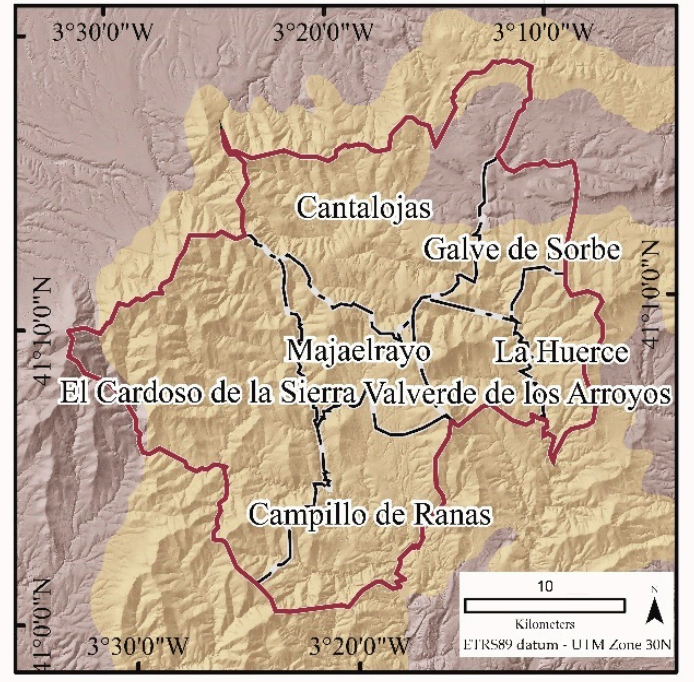

Case study Administrative units Landscape unit
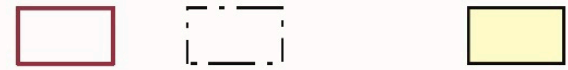

Figure 1. Map of the case study areas-Estrela massif (A, approx. 58 thousand hectares) and Ayllón massif (B, approx. 63 thousand hectares)-Showing the topography in shaded relief, the boundaries of the landscape units and the administrative units within them. Source: DEM and boundaries layers-National Geographic Institute (Portugal, http://www.dgterritorio.pt and Spain, http://centrodedescargas.cnig.es). 
Geology: The Central Mountain System is lithologically and structurally complex. It is composed of diverse mesostructures and macrostructures that are a product of metamorphic, granitization and other regional deformational processes, especially in the Cenozoic Era [56]. The Estrela massif ranges from $400-1993 \mathrm{~m}$ asl and it is dominated by granites, slate and greywacke parent material. Elevation in the Ayllón massif ranges from 700-2272 m asl and it is dominated by black slate and gneiss, clay slate and granite parent material [57]. The soils in the two massifs are quite similarly coarse textured and of low productivity.

Climate: There is abundant rainfall from repeated storms in both the Estrela and Ayllón massifs [58]. The Estrela massif has influences of temperate and Mediterranean climates with an average annual temperature of $9{ }^{\circ} \mathrm{C}$ (average maximum of approx. $15^{\circ} \mathrm{C}$, average minimum of approx. $5{ }^{\circ} \mathrm{C}$ ), and average annual rainfall of 2000-2500 mm [59]. In the Ayllón massif, the dominant climate is sub-Mediterranean with an average temperature of about $8{ }^{\circ} \mathrm{C}$ (average maximum of approx. $20^{\circ} \mathrm{C}$ and average minimum of approx. $1^{\circ} \mathrm{C}$ ) and average annual rainfall of $800-1500 \mathrm{~mm}$ [60]. Both are continental climates with warm summers and mild, wet winters.

Population and activities: In both massifs, there was a sharp downward trend in human population starting in the 1960s. However, whereas in Estrela, the population was growing before that date [61], in Ayllón there was a smooth decreasing trend from the 19th century [62]. The Estrela massif once had a vigorous industrial sector based on livestock and wool production that now does not exist. Nowadays one of the most important economic activities is tourism linked with the Estrela Natural Park created in 1976. In the Ayllón massif, although livestock production for meat is less important than it was historically, it still plays a very important economic and social role after being reinvented at a smaller scale. Tourism also generates incomes thanks to the Natural Park of the Guadalajara Northern Mountains (of which the first section was created in 1978) and with the Black Architecture Villages of the Guadalajara Mountains.

Vegetation composition: The Estrela massif is dominated by transitional woodland-shrubs. The tree layer at lower altitudes is mainly composed of Quercus sp., and in the cooler areas there is Fraxinus sp. as well as other varied riparian vegetation. At intermediate altitudes, Quercus sp., Calluna sp. and Cytisus sp. occupy the majority of the area. These latter two, along with Juniperus sp., peatlands, mountain pastures, and particularly Cytisus sp. and Nardus stricta grasslands dominate the higher altitudes of the Estrela massif, with a tree layer composed largely by Pinus sp. [63,64]. In the Ayllón massif there are Quercus sp. and Juniperus communis, and in the cooler areas there is also Fagus sylvatica. The areas at higher altitudes are dominated by shrubs such as Erica sp., Calluna sp., Cistus sp. and Lavandula sp, and the tree layer is composed mainly of Pinus sp. (natural and from reforestations) and Quercus pyrenaica [65-67].

\subsection{Data Gathering}

LULC data: To facilitate comparison of LULC changes between the two case study areas, we used the CORINE Land Cover inventory. These LULC maps from 1990 allow for multi-temporal analyses of LULC [68-70]. These data are provided by the European Union's Earth Observation Programme - Copernicus Land Cover Products (https://land.copernicus.eu/pan-european/corine-landcover) coordinated by the European Environment Agency (https://www.eea.europa.eu). The minimum mapping unit is 25 hectares, scale is 1:100,000, and it is classified into 44 thematic categories (of these, 25 are present in our case study area). We analyzed data for the four years for which the CORINE Land Cover inventory data were available: 1990, 2000, 2006 and 2012 (Table 1). We reclassified the 25 thematic categories into six new categories: Artificial surfaces, Agriculture and Agroforestry, Pastures, Forest, Shrubland, and Water bodies (Table S1). The last category (Water bodies) corresponds to less than $0.5 \%$ of the total area in the two case study areas, and we did not include it in our analysis. 
Table 1. LULC data sources used in this study.

\begin{tabular}{|c|c|c|c|c|}
\hline Map & $\begin{array}{c}\text { Period of } \\
\text { Data Collection }\end{array}$ & $\begin{array}{c}\text { Year of } \\
\text { Reference }\end{array}$ & Map Scale & $\begin{array}{c}\text { Geometric Accuracy } \\
\text { of the CORINE Land } \\
\text { Cover Inventory }\end{array}$ \\
\hline Agriculture and Forestry Map-Portugal & 1963-1980 & 1972 & $1: 25,000$ & - \\
\hline OrthophotoMap-Spain & 1956-1957 & 1956 & $1: 32,000$ & - \\
\hline CORINE Land Cover inventory 1990 & $1986-1998$ & 1990 & $1: 100,000$ & $100 \mathrm{~m}$ \\
\hline CORINE Land Cover inventory 2000 & 1999-2001 & 2000 & $1: 100,000$ & Better than $100 \mathrm{~m}$ \\
\hline CORINE Land Cover inventory 2006 & $2005-2007$ & 2006 & $1: 100,000$ & Better than $100 \mathrm{~m}$ \\
\hline CORINE Land Cover inventory 2012 & 2011-2012 & 2012 & $1: 100,000$ & Better than $100 \mathrm{~m}$ \\
\hline
\end{tabular}

In order to have an overview of the general distributional LULC mosaic at the time of the first acknowledged shift of the fire regime in the 1970s, we analyzed the $20-30$ years before the first CORINE Land Cover inventory in 1990. For that, we used the Portuguese Agriculture and Forestry Map from the year 1972, which was already displayed with the six classes legend we used. It was provided in vectorial format by the University of Lisbon and it is not available online. We also used the Spanish OrthophotoMap from 1956, released by the Cartographic Centre of Castilla-La Mancha in raster format (http://centrocartografico.castillalamancha.es), and which we have processed through photointerpretation to a vectorial format using the same six classes. Because the scales of both of these latter products differ from the CORINE Land Cover inventory (Table 1), in order to avoid inconsistencies, they were used only to frame the following periods and were not applied to analyze LULC transitions.

For analyzing forest composition changes, we used the official Portuguese and Spanish National Forest Inventories established in the 1960s, which similarly enables multi-temporal analyses [71]. We used the National Forest Inventory Maps when they were available and the National Forest Inventories (NFI) when no map was available. The Centro de Ecologia Aplicada 'Prof. Baeta Neves' (CEABN) provided the NFI and the NFI maps for the Estrela massif case study (not available online), and the Spanish Ministry of Agriculture provided the NFI Maps for the Ayllón massif case study (https://www.mapa.gob.es/es/desarrollo-rural/temas/politica-forestal/inventario-cartografia/ inventario-forestal-nacional/default.aspx). Both Portuguese and Spanish NFI have an average interval of 10 years. All of the three available Spanish NFI are accompanied by a vectorial NFI Map with polygons (1:400,000 in 1971 to 1:50,000 in 2002), thus we used the three of them with the following years of reference: 1971, 1991, and 2002. The fourth, corresponding to 2013, remains unpublished (Table 2). The Portuguese NFI is not always accompanied by a map. The only NFI Map is for 1974. The rest of the Portuguese NFI are vectorial infopoint grids with different distance between points ( 700-750 $\mathrm{m}$ in 1995, and $500 \mathrm{~m}$ in 2005), resulting from a variable number of location plots that became permanent in the fifth NFI [72]. For Portugal, the last NFI is unpublished, and the first (1964) and third (1984) NFIs are not available. Therefore, we used the three of them with the following years of reference and formats: 1974 (Map), 1995 (Infopoint grid), and 2005 (Infopoint grid). Both countries have their own legends and the number of thematic categories increased with time (Portugal: $~ 15$ main forest categories in 1974 and $~ 55$ forest categories in 2005; Spain: 30 forest categories in 1971 and $>100$ forest categories in 2002). From all the NFI categories in all years of reference, 11 forest categories of the Portuguese NFI are present in the Estrela massif, and 19 forest categories of the Spanish NFI are present in the Ayllón massif. Additionally, 21 shrub categories are present in the Ayllón massif. We reclassified the forest categories into five new categories: Pinus sp., Other Conifers, Quercus sp., Other Broadleaved + Mixed forest, and Shrubland, plus one category of non-forest (Other) (Table S2). The Shrubland category, as well as the Other category, are used only for the analysis of the interaction of forest composition and fire in the Ayllón massif, and for that reason this category was not included in reclassification for the Estrela massif. Although they do not exactly coincide in dates, these two products (CORINE Land Cover inventory and NFI) are complementary for our study, because they coincide in 1990s-2000s providing very useful multi-temporal information about LULC and forest composition, respectively. 
Table 2. National Forest Inventory data for Portugal and Spain used to characterize forest composition through time in the two massifs. "NA" means that the data is not available to use. "Dbp" means distance between the grid points.

\begin{tabular}{|c|c|c|c|c|}
\hline & NFI & $\begin{array}{l}\text { Period of Data } \\
\text { Collection }\end{array}$ & $\begin{array}{c}\text { Year of } \\
\text { Reference }\end{array}$ & Format \\
\hline \multirow{6}{*}{ Portugal } & 1st Portuguese NFI & 1963-1965 & 1964 & NA \\
\hline & 2nd Portuguese NFI & $1968-1980$ & 1974 & Vectorial (Polygon) 1:25,000 \\
\hline & 3rd Portuguese NFI & 1980-1989 & 1984 & NA \\
\hline & 4th Portuguese NFI & 1990-2001 & 1995 & $\begin{array}{l}\text { Vectorial (Infopoint grid) } \\
\text { Dbp: 700-750 }\end{array}$ \\
\hline & 5th Portuguese NFI & 2004-2007 & 2005 & $\begin{array}{l}\text { Vectorial (Infopoint grid) } \\
\text { Dbp: } 500\end{array}$ \\
\hline & 6th Portuguese NFI & $\begin{array}{c}\text { 2010-2015, } \\
\text { Unpublished }\end{array}$ & 2012 & Unpublished \\
\hline \multirow{4}{*}{ Spain } & 1st Spanish NFI & 1967-1974 & 1971 & Vectorial (Polygon) 1:400,000 \\
\hline & 2nd Spanish NFI & 1986-1995 & 1991 & Vectorial (Polygon) 1:200,000 \\
\hline & 3rd Spanish NFI & 1997-2007 & 2002 & Vectorial (Polygon) 1:50,000 \\
\hline & 4th Spanish NFI & $\begin{array}{l}\text { 2008-2019, } \\
\text { Ongoing }\end{array}$ & 2013 & Unpublished \\
\hline
\end{tabular}

Fire data: We used the Portuguese official statistical fire data (IF-ICNF), provided by Nature Conservation and Forests Institute (ICNF) since 1980 http://www2.icnf.pt/portal/florestas/dfci/inc/ estat-sgif) to know both fire frequency and fire perimeters in the Estrela massif. We used the Spanish official statistical fire data provided by the Agriculture Ministry from 1968 (EGIF, https: //www.mapa.gob.es/es/desarrollo-rural/estadisticas/Incendios_default.aspx) to know the fire frequency, and we used the Castilla-La Mancha autonomous community fire perimeters data (IF-CLM) provided by the Spanish Guadalajara Provincial Council since 1968 (not available online) to know the fire perimeters. Both IF-ICNF and IF-CLM data contain various fire variables, including location, burned area, and fire perimeter, with varying accuracy. However, records of fire perimeters differ. The IF-ICNF provides the perimeter for all fires since its first records in 1980, while the IF-CLM did not include fires smaller than 1 hectare. All fires larger than 1 hectare are included in these data; they were reconstructed from paper documents and corrected using satellite images and orthophotos by [73]. This means that we know the fire frequency using the EGIF (which includes fires smaller than 1 hectare, but does not include the fire perimeters), and we know the fire perimeters using the IF-CLM, although it does not include fires smaller than 1 hectare. These fires smaller than 1 hectare in Ayllón do not represent a large area ( 20 hectares from 1990-2011).

In order to validate the comparison between fire databases from the two different countries, we overlapped the European Forest Fire database (EFFIS) (a satellite image-based database) [74], with the national fire databases (IF-ICNF and IF-CLM) for the period 2000-2011. The results showed that $87 \%$ of the fire perimeters match in the Estrela massif, but only $7 \%$ of fire perimeters match in the Ayllón massif (Figure S1), likely because small fires are less likely to be detected by satellites or because some parts did not burn intensely or severely enough to be detected in the satellite data. The remaining fires in both cases is not represented in the EFFIS data. Therefore, the data from the national databases is sufficiently complete and comparable for the objectives presented in this paper.

\subsection{Data Analysis}

The spatial scale used for the analysis was the landscape scale (see Table 1 for spatial resolution), applied to the two case study areas: the Estrela massif and the Ayllón massif. The temporal scale ranges from 1972-2012 for Estrela, and 1956-2012 for Ayllón. 
We compiled, edited and geoprocessed LULC and forest composition data in the GIS ArcMap application (ESRI 2011. ArcGIS Desktop: Release 10. Redlands, CA: Environmental Systems Research Institute). All the analyses of the geoprocessed data were performed in Microsoft Office Excel as follows (see Methodology flowchart, Figure S2).

First, for a general overview of the LULC distribution in the five years of reference in the Estrela and Ayllón massifs (Table 1), we calculated percentages in the total area of each of the six LULC categories in each case study area. Thus, for the Estrela massif we calculated for the years 1972, 1990, 2000, 2006 and 2012; for the Ayllón massif we calculated for the years 1956, 1990, 2000, 2006 and 2012.

Second, to understand the main LULC dynamics in both massifs, we excluded the first year of reference (1972 for Estrela and 1956 for Ayllón). We calculated the percent changes in area from 1990 (percent changes in area of each LULC category from one LULC map to the next). We grouped the dynamics into five classes (forest progressive trend, forest regressive trend, loss of agricultural land, land use stability, and other land use changes). Forest progressive trend means to change from shrubland into forest. Forest regressive trend means the opposite. Loss of agricultural land was separated as a new dynamic due to the importance of the agricultural land and pastures in these rural areas. Land use stability refers to those areas that did not change. Other land use changes class includes the change from the category Other into all other categories, as well as the change from all other categories into the Other category.

Third, we analyzed possible LULC and fire interactions by overlapping the LULC maps (1990-2000, 2000-2006, 2006-2012) and the fire perimeters for each corresponding period (1990-1999, 2000-2005, and 2006-2011) and classifying the resulting areas as Fire (F) and No Fire (NF). With these results, we then built three simple mathematical transition matrices (according to the Markov model [75]), which represent the LULC changes between the selected time periods (1990-2000, 2000-2006 and 2006-2012) for $\mathrm{F}$ and NF. Then, we computed a global transition matrix using the weighted average of the values of the three periods for F and NF. We used the burned area for each LULC category in each period as the weighting factor for $\mathrm{F}$.

Fourth, we used Manly's selectivity index [76] to assess which LULC categories were more likely or less likely to burn than their area would suggest. We compared the area of each LULC category that burned (within the total burned area of all LULC categories), and the area of the same LULC category available before the fire (within the total area of all LULC categories). Thus, for each LULC category we used:

$$
\alpha_{i}=\frac{\text { Burned area of LULCcategor } y_{i} / \text { Total burned area }}{\text { Area of LULCcategory } y_{i} / \text { Total area }}
$$

If this index is higher than 1, we interpreted this as fire was selective for a LULC category because the proportion of the burned area of that LULC category was higher than the proportion of the available area of the same LULC category. Conversely, if it is lower than 1, it means that fire did not showed selectivity for that LULC category.

Lastly, using only the case study of the Estrela massif, where major changes occurred, we used simple linear regressions to explore the possible relationships between percent change in the main LULC categories (shrubland, forest, and agriculture and agroforestry) and percent area burned in the corresponding category, for the 1990-2000, 2000-2006, and 2006-2012 periods. The burned area in the Ayllón massif case study is too small to successfully perform the same exploration.

In order to overcome the fact that maybe some changes are not apparent due to the aggregation of the forest LULC category, we then investigated the forest composition (FC) within the forest LULC category. Although the NFI varied in format and scale, the comparison of FC between the two massifs using percentages is reasonable. For the Portuguese FC in the three years of reference (1974, 1995, and 2005), we calculated percentages of points within the total area of each of the four FC categories (shrubland category not included). For the Spanish FC in three years of reference (1971, 1991, and 2002), we calculated percentages in the total area of each of the four FC categories. To analyze the interaction between FC and fire, we focused only on the Ayllón case study area, because the associated 
NFI Maps enabled this. The burned area is not very large, thus we joined the categories Pinus sp. and Other Conifers into one broader category that is Conifers. Similarly, we joined the category Quercus sp. and Other Broadleaved + Mixed forest into one broader category that is Broadleaved + Mixed forest. The method was the same as used for LULC and fire interaction analysis, but using the NFI Maps instead, and considering two time periods according to the dates of the Spanish NFI Maps: 1971-1991 and 1991-2002. In addition, the correspondent periods of burned area used were, respectively, 1971-1990 and 1991-2001. Likewise, we compared the area of each FC category burned and the area of the same FC category available before the fire for the Ayllón massif, using the same selectivity index previously explained for LULC (see Methodology flowchart, Figure S2). Finally, following the same method applied to LULC explained above, two transition matrices were built, representing the FC changes between the selected time periods (1971-1991 and 1991-2002) for burned (F) and unburned (NF) in the Ayllón massif.

\section{Results and Discussion}

\subsection{Land Use/Land Cover Changed through Time}

LULC over time differed between the two ends of the Central Mountain System. In the Estrela massif, there was a small decrease in forest and a similar increase in shrubland for the 1972-2012 period (Figure 2A). In this massif, shrubland was the most extensive LULC category as it represented more than $50 \%$ of the total area during all years analyzed. Forest LULC was also abundant (more than $17 \%$ in all years), with agriculture and agroforestry (more than $10 \%$ in all years) and pastures (less than $4 \%$ in all years) also present. In 1972, 31\% of the Estrela massif was forested, which is confirmed by official reforestation reports for 1970s [77]. Conversely, trends were not linear in the Ayllón massif. Until the end of the 20th century, shrubland area increased slightly, but after the year 2000, there was a sharp decrease of shrubland area, along with an increase in forest and pasture in 1990-2000 (Figure 2B). The most extensive LULC category in this massif was shrubland until $2000(\sim 55 \%$ in all years until 2000), and forest after 2000 (38\% after 2000), followed by pastures ( $9 \%$ until 2000 and $23 \%$ after 2000), and agriculture and agroforestry (less than $7 \%$ in all years).

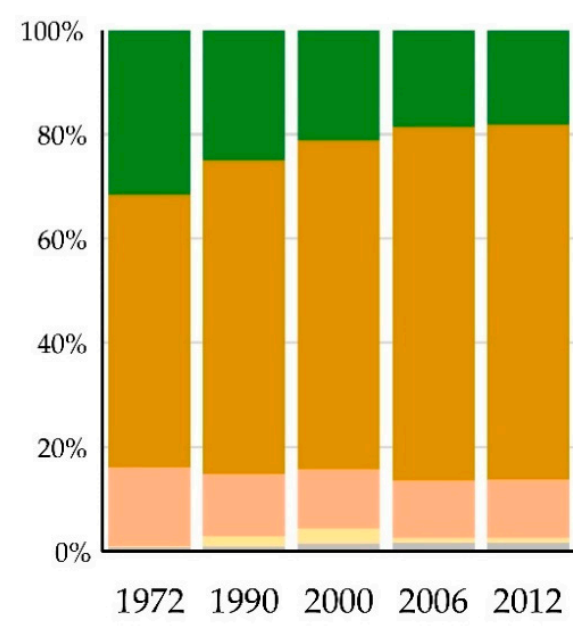

(A)

Estrela massif

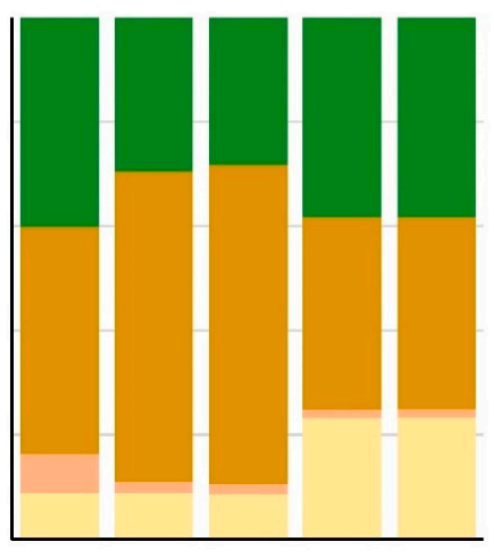

19571990200020062012
Forest

Shrubland

Agriculture and Agroforestry

Pastures

Artificial surfaces

(B)

Ayllón massif

Figure 2. LULC (percent of total land area) in the Estrela massif (A) and in the Ayllon massif (B) in the second half of the 20th century.

The striking difference between the two massifs is that agriculture and agroforestry areas (corresponding to non-irrigated arable land) were more extensive in the Estrela massif, while pastures were always more important in the Ayllón massif. Such difference in LULC reflects the dissimilar socio-economic backgrounds. In Estrela, the system was based more on agriculture and agroforestry, 
while in Ayllón cattle grazing for meat production dominated [78,79]. LULC changes in both areas reflect the socio-economic outcomes of the post-World War II years, which in Portugal were very much linked to the stability or slight increase of agriculture areas until the 1970s (Figure 2A). These changes in agriculture areas were accompanied by a modernization of the rural areas (markets opening, agriculture mechanization, new fertilizers and feed-grain became available), as well as, by an exodus of residents from rural areas [80]. Through the 1970s, pasture-related activities and animal production decreased in the whole country and the poorer pasture areas were abandoned [81]. In Estrela in 1972 there is very little area of pastures (Figure 2A). In the wake of the first oil crisis in 1973, the economic growth slowed, as did the rural abandonment in Portugal, with exception to the mountain areas, as the Estrela massif, which kept this rural abandonment trend [82]. Around the same time, and as a result of the 1974 Carnation Revolution, the mass repatriation of people after the independence of the former Portuguese African colonies could have helped to raise the human population in the Estrela massif, as it did in many areas of Portugal [83], but actually it could not stop the declining trend started around the 1960s [61]. Our results show that the agriculture and agroforestry areas did not vary much in extent. The increase in the area of pastures could only reflect more available land due to land abandonment because the number of shepherds decreased more than $50 \%$ between 1970s and 2012, as did the number of livestock in Estrela [84]. The Ayllón massif, being Spanish, reflected different socio-economic outcomes. Here, the decrease of agriculture and agroforestry areas until 2000 (Figure 2B) is explained by the selective reduction of agriculture areas that happened all over Spain as land was abandoned [85], and continued human population loss in the Ayllón massif [62]. The increase in pasture areas was an outcome of the change in the livestock agro-business models (e.g., more cows and less goats) boosted by the large size of the common properties that characterize this massif [86]. Both Estrela and Ayllón share the Common Agricultural Policy membership and EU membership of their respective countries since 1986, whose policies started being fully evident after 1990 in the decline in the value of the forest resources [87]. Estrela, having been characterized by family farming and smallholdings, was more shaken by these two changes than was Ayllón. Therefore, Estrela maintained a small-scale production of traditional sheep cheese and started focusing on the tertiary sector of the economy, with predominance for rural tourism, whereas, besides the focus on tourism and a weaker tertiary sector, Ayllón also specialized in open range cattle grazing for meat production [88]. New market conditions led to adaptation in the rural system in the Ayllón massif. In the face of the land abandonment that happened in both massifs, there were different observed trends concerning shrubland: increase of shrubland area in Estrela during all the years analyzed (as verified in other Mediterranean landscapes [89]), and the turnaround of this increasing trend after 2000 in Ayllón.

During the second half of the 20th century, LULC in the Estrela massif was more stable than in the Ayllón massif ( $~ 86 \%$ of land use stability in Estrela and $\sim 82 \%$ of land use stability in Ayllón). This is in line with the national trend of the two respective countries as LULC in Portugal was more stable compared to Spain [90]. Also in agreement with the national trends, the leading LULC changes in the Estrela massif were directly related to forests $[68,91]$, with forest regression higher than its progressive development (for the 1990-2000 and 2000-2006 periods, more than 30\% of forest transitioned to shrubland) (Figure 3A). This same trend of forest regression can be seen in the Ayllón massif, especially between 2000 and 2006, when much of the forest transitioned to shrubland and pastures, and when much shrubland area transitioned to pastures (Figure 3B). On the other hand, forest area increased as a result of the national reforestation efforts in Portugal and in Spain in the mid-20th century, carried out for hydrological-woodland restoration and erosion control in the upper parts of watersheds, and fast wood production of Pinus sp. stands elsewhere [92]. In both Estrela and Ayllón, these extensive, reforestation efforts were carried out by the respective Portuguese and Spanish Forest Administrations through land acquisition, expropriation or occupation [93,94]. In both massifs, reforestation resulted in less land available for grazing livestock, which caused considerable social troubles for the local people, and ultimately limited reforestation to less than originally planned [67]. 
(A)

\begin{tabular}{|c|c|c|c|c|c|c|c|c|c|c|c|c|c|c|c|}
\hline \multirow[b]{2}{*}{ Land use classes } & \multicolumn{15}{|c|}{ To } \\
\hline & \multirow[t]{2}{*}{$1990-00$} & \multirow[t]{2}{*}{$\begin{array}{c}\text { Forest } \\
2000-06 \text { । }\end{array}$} & \multirow[t]{2}{*}{$2006-12$} & \multirow{2}{*}{$\frac{1990-00 ।}{31 \%}$} & \multicolumn{2}{|c|}{$\begin{array}{l}\text { Shrubland } \\
\text { | 2000-06 | 2006-12 }\end{array}$} & $1990-00$ & \multicolumn{2}{|c|}{$\begin{array}{l}\text { Pastures } \\
\text { | 2000-06 | 2006-12 }\end{array}$} & \multicolumn{3}{|c|}{$\begin{array}{l}\text { Agriculture and Agroforestry } \\
1990-00|2000-06| 2006-12\end{array}$} & \multicolumn{3}{|c|}{$\begin{array}{c}\text { Other } \\
1990-00 \mid 2000-06 \text { | 2006- } 12\end{array}$} \\
\hline Forest & & & & & $37 \%$ & $9 \%$ & $1 \%$ & $0 \%$ & $0 \%$ & $0 \%$ & $0 \%$ & $0 \%$ & $0 \%$ & $0 \%$ & $0 \%$ \\
\hline Shrubland & $7 \%$ & $8 \%$ & $2 \%$ & & & & $2 \%$ & $0 \%$ & $0 \%$ & $0 \%$ & $1 \%$ & $0 \%$ & $0 \%$ & $0 \%$ & $0 \%$ \\
\hline Pastures & $2 \%$ & $6 \%$ & $0 \%$ & $20 \%$ & $66 \%$ & $0 \%$ & & & & $1 \%$ & $0 \%$ & $0 \%$ & $0 \%$ & $0 \%$ & $0 \%$ \\
\hline $\begin{array}{l}\text { Agriculture and } \\
\text { Agroforestry }\end{array}$ & $2 \%$ & $3 \%$ & $0 \%$ & $1 \%$ & $3 \%$ & $0 \%$ & $0 \%$ & $0 \%$ & $0 \%$ & & & & $4 \%$ & $1 \%$ & $0 \%$ \\
\hline Other & $0 \%$ & $0 \%$ & $0 \%$ & $2 \%$ & $0 \%$ & $0 \%$ & $0 \%$ & $0 \%$ & $0 \%$ & $1 \%$ & $0 \%$ & $0 \%$ & & & \\
\hline (B) & ogressiv & re trend & \multicolumn{3}{|c|}{ Forest regressive trend } & \multicolumn{4}{|c|}{ Loss of agricultural land } & \multicolumn{6}{|c|}{ Land use stability $\quad$ Other land use changes } \\
\hline Land use classes & $1990-00$ & $\begin{array}{r}\text { Forest } \\
\text { | } 2000-06 \\
\end{array}$ & | 2006-12 & 1990-00 & $\begin{array}{l}\text { Shrubland } \\
\mid \text { 2000-06 | }\end{array}$ & 2006-12 & 1990-00 & $\begin{array}{c}\text { To } \\
\text { Pastures } \\
\text { | 2000-06 | }\end{array}$ & 2006-12 & $\begin{array}{l}\text { Agricul } \\
1990-0\end{array}$ & $\begin{array}{l}\text { re and } A \\
2000-06\end{array}$ & $\begin{array}{l}\text { oforestry } \\
2006-12\end{array}$ & 1990-00 & $\begin{array}{c}\text { Other } \\
\text { | 2000-06 }\end{array}$ & $2006-12$ \\
\hline Forest & & & & $6 \%$ & $16 \%$ & $0 \%$ & $0 \%$ & $11 \%$ & $0 \%$ & $0 \%$ & $0 \%$ & $0 \%$ & $0 \%$ & $0 \%$ & $0 \%$ \\
\hline Shrubland & $0 \%$ & $26 \%$ & $0 \%$ & & & & $0 \%$ & $24 \%$ & $0 \%$ & $0 \%$ & $0 \%$ & $0 \%$ & $0 \%$ & $0 \%$ & $0 \%$ \\
\hline Pastures & $2 \%$ & $13 \%$ & $0 \%$ & $0 \%$ & $20 \%$ & $0 \%$ & & & & $3 \%$ & $10 \%$ & $0 \%$ & $0 \%$ & $0 \%$ & $0 \%$ \\
\hline $\begin{array}{l}\text { Agriculture and } \\
\text { Agroforestry } \\
\end{array}$ & $0 \%$ & $13 \%$ & $0 \%$ & $26 \%$ & $28 \%$ & $0 \%$ & $0 \%$ & $32 \%$ & $0 \%$ & & & & $0 \%$ & $0 \%$ & $0 \%$ \\
\hline Other & $0 \%$ & $11 \%$ & $0 \%$ & $0 \%$ & $19 \%$ & $0 \%$ & $0 \%$ & $3 \%$ & $0 \%$ & $0 \%$ & $0 \%$ & $0 \%$ & & & \\
\hline
\end{tabular}

Figure 3. LULC dynamics in the Estrela massif (A) and in the Ayllón massif (B) in the second half of the 20th century. Tables are read from line (where it is written "From") to column (where it is written "To"), and each line sums $100 \%$ for each period. Values in the tables are the percentages of the area that remain in the same vegetation class or change from one period to the next. Note that the individual columns for each LULC represent each of the three time periods (1990-2000, 2000-2006, and 2006-2012).

The loss of agricultural land between 2000 and 2006 occurred in both massifs, which may have been associated with the EU policies and with land degradation [95-97]. Between 2000 and 2006 in Estrela, $66 \%$ of pastures changed into shrubland, while in Ayllón, $28 \%$ of agriculture and agroforestry, and $20 \%$ of pastures, changed into shrubland (Figure 3). A loss of agricultural land followed by natural and artificial reforestation existed in both study areas, except in the period 2006-2012 when the massifs were characterized by landscape stability (Figure 3). This conversion from agriculture land into forest, when for economic advantages, is one of the acknowledged reasons for forest transition [98]. If, in one hand, forest transition is confirmed for the Ayllón massif [99], our results for Estrela (only $2 \%-6 \%$ of change from agricultural land into forest) indicate that forest transition is not relevant. In fact, Oliveira et al. [54] confirms our results, having found that even from earlier, from the 1970s-2006, the Estrela massif had areas where forest transition did not exist or had failed.

\subsection{Fire and Land Use/Land Cover Are Related}

In Estrela, for the 1990-2011 period, 5796 fires were recorded with a total burned area of $\sim 44$ thousand hectares (Figure 4A). Approximately 723 hectares of that total area burned in fires smaller than 1 hectare equally distributed between the three time periods. In Ayllón, for the same 1990-2011 period, only 142 fires were recorded, with a total burned area of 2636 hectares (Figure 4B). The annual fire frequency and burned area were not linear through 1990-2011, the years 1994 and 1995 corresponded to a peak in the fire frequency in Estrela, and a peak in the burned area in Ayllón, as in the entire Iberian Peninsula [28]. The IF-ICNF database also provide us the information about the major cause of fires being accidental in Estrela, mostly related with agroforestry and agriculture. The major cause of fires in Ayllón was lightning, followed by accidental ignition related with agriculture, according to the Spanish national forest fire database. Fire causes related with agriculture activities in both massifs are not surprising, because previous studies have shown this cause as the most frequent 
in rural areas in Spain and in Portugal [100-103], as it is also investigated the high rate of fire by lightning in the Northern west area of the Ayllón massif [104,105]. It is, however, interesting, that fire activity has developed along such distinct paths in the two massifs, with Estrela having a much higher number of fires and area burned. The reasons for this difference will be discussed later in the text. Nevertheless, it can be pointed out at this stage that both massifs had wildfires larger than 500 hectares before the year 2000, which according to literature points to, inter alia, the changes in LULC and population distribution of the earlier years [2,106]. After 2000, fires in the Ayllón massif were smaller, matching smaller LULC changes in this time period (Figure 3). We know that after 2000 the human population declined in both Estrela and Ayllón. It may suggest that the greater decline in both people and agriculture in Estrela may accounts for the increase in area burned and likely the larger fires (after 2000, 2764 hectares was the maximum fire size in Estrela and 549 hectares was the maximum fire size in Ayllón) (Figure 4). Others have found that the role of the wildfires drivers change over time and scale [45,52], which had led us to explore the relation between burned area and LULC at the landscape scale of these two massifs through three different time periods.

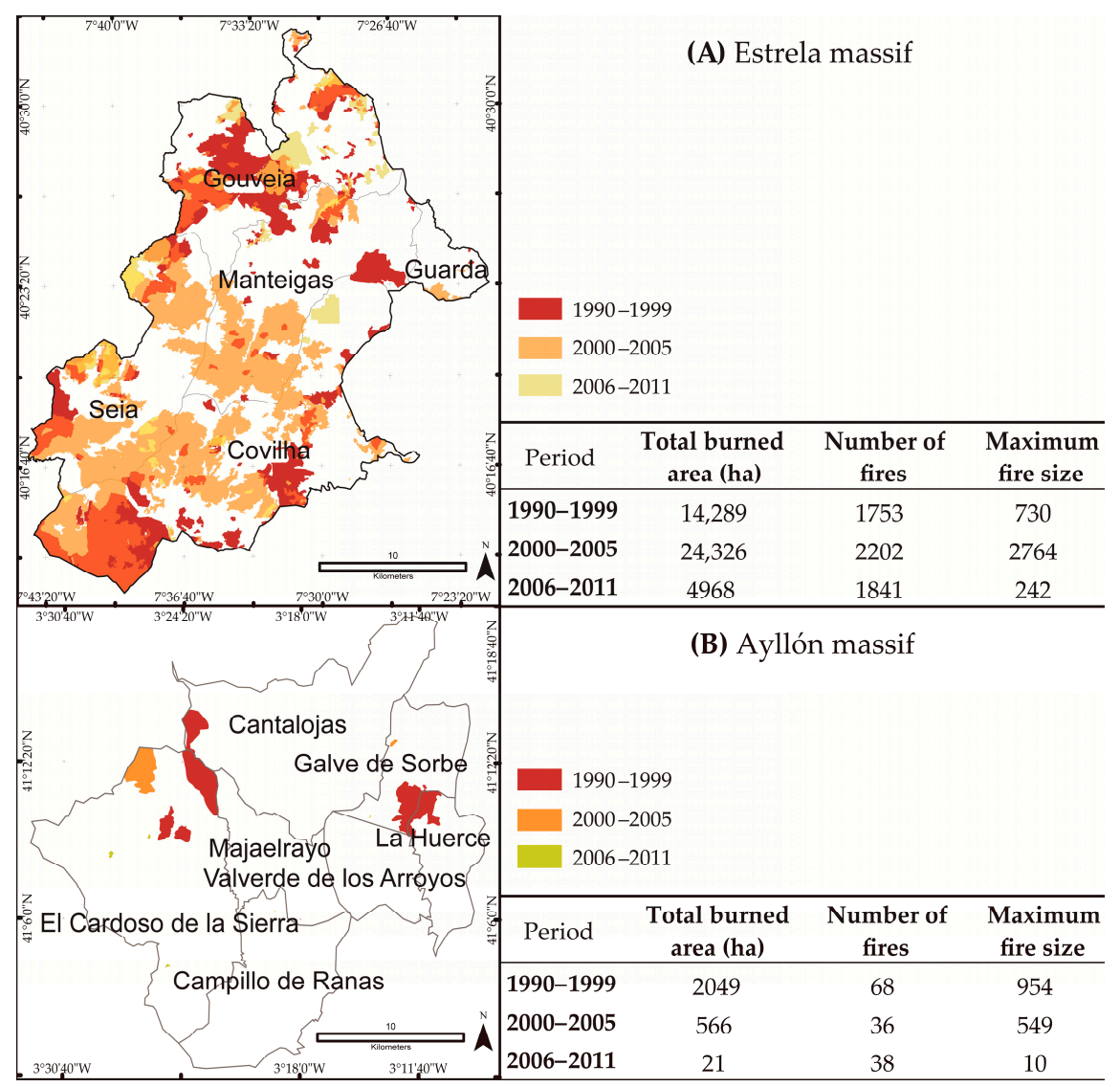

Figure 4. Fire characteristics and burned area for the 1990-1999, 2000-2005, and 2006-2011 periods in the Estrela massif (A) and in the Ayllón massif (B).

In the Estrela massif, fires occurred selectively in areas of shrubland, pastures, and forest (Figure 5A). Between 1990 and 2000 all three of them were similarly burned, between 2000 and 2006 only shrubland and pastures were similarly burned, and between 2006 and 2012 shrubland areas were the only LULC category preferentially burned. While not statistically significant, as it is based on only three transitions, there seems to exist a positive association between shrubland and fire in the Estrela massif, because even when the burned area was small in one time period, shrubland area increased in that same time period (Figure 5C). Similarly, the associations between fire and both the forest and agriculture and agroforestry LULCs seem to be negative, with fire decreasing the original areas of these 
LULC categories as other authors also confirmed for forests [52]. In Ayllón, fire also occurred selectively in areas of shrubland, pastures, and forest (Figure 5B), but the LULC category that burned the most varied in each period. Between 1990 and 2000 it just occurred selectively in forest, between 2000 and 2006 it just occurred selectively in shrubland, and between 2006 and 2012 it occurred selectively in pastures and shrubland. In this massif there were not continuing trends and fire seems to have become less selective than in the Estrela massif. In general, results are consistent with previous studies suggesting that shrubland and pastures are more fire prone than agriculture [23,40,107], and that forests are less fire-prone with time in Spain [52]. There was an interesting difference between the two massifs: until 2006, fire occurred selectively in pastures only in Estrela, and after 2006 it occurred selectively in pastures only in Ayllón (Figure 5A,B). On the one hand, in Central Spain pastures tended to burn more as time goes [52]. On the other hand, pastures selectivity differences are likely explained by the association between fire and livestock activities. In the Ayllón massif, the number of livestock units (according to the census of agriculture $[108,109]$ ) and area of pastures are both higher than in Estrela, which could limit the amount of available fuel to burn making fire less needed for managing pasture vegetation. Conversely, in Estrela, where there is less livestock units, there is a higher rate of fuel accumulation and more burning is needed to maintain pastures. This view is supported by fire-smart management strategies, either by prescribed burning linked with the pastoral activities $[110,111]$ and by livestock husbandry of ruminant animals $[112,113]$, and highlights the importance of the different socio-economic contexts.

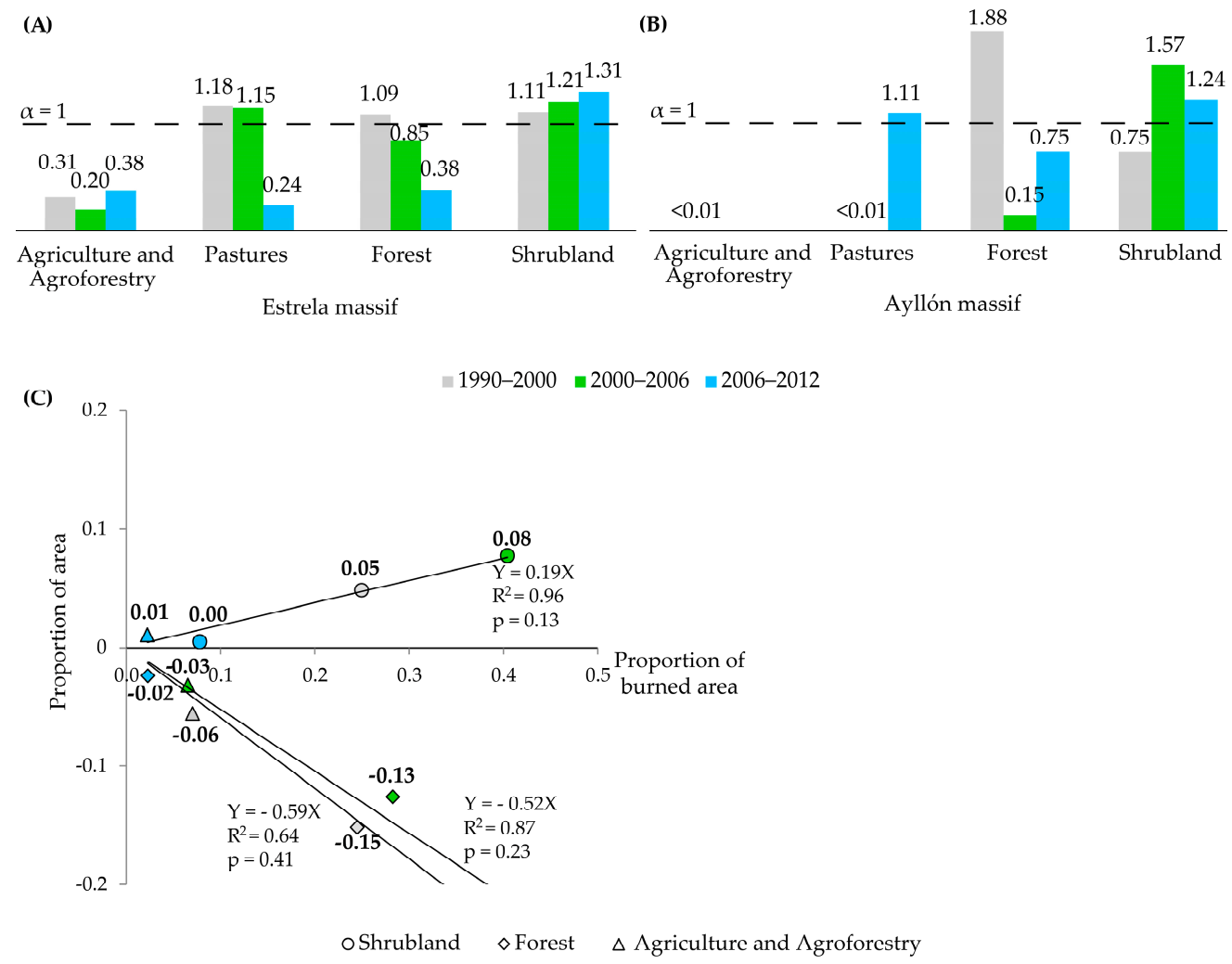

Figure 5. Fire selectivity index, based on Manly's index [76], in the Estrela massif (A) and in the Ayllón massif (B), and simple linear regression of the relationships between the main LULC categories (shrubland represented by the circle, forest represented by the rhombus, and agriculture and agroforestry represented by the triangle) and burned area in the Estrela massif: proportion of LULC category area increased (positive numbers) or decreased (negative numbers) vs. proportion of burned area (C). The color code is the same for A, B and C.

Our results suggest that fire is associated with LULC changes, which is in line with other studies (e.g., [13]). In the Estrela massif, the shrubland area increased with area burned, regardless of the initial 
LULC category. Moreover, the outcome of fire absence was a slight increase in the forest area in all LULC categories except forest (Figure 6A). In Ayllón, fire absence seems to have had the same effect that it had in Estrela, because here there was also an increase in forest, and fire likely favored the increase in shrubland (Figure 6B). On the other hand, in Ayllón, pasture areas have increased, transitioning from all LULC categories without fire, possibly in relation to human activities favoring pasture areas. It differs from Estrela, where many pastures were abandoned and converted to shrubland, likely not because of fire, but because of less livestock grazing activities. In both massifs, the decrease in forest area coincided with burning, and shrubland dominated with or without fire. We conclude that for the 1990-2000 period, when fire occurred selectively in forest in both massifs, the transition from forest to shrubland was caused largely by fire. This dynamic of forest regression supports the linkage between reforestations and fire suggested by various authors [54,114,115], because the areas burned between 1990 and 2000 were often those reforested in the previous decades. With less area of pastures and agriculture, the landscapes were fire-prone. Our results suggest that after 2000, area burned was not directly related to burning of forest area anymore, but was still a result of the reforestations, by the high flammability of shrubland resulting also from forest conversion. Thus, we think that fire associated with the socio-economic context were likely important drivers of LULC changes in Estrela and in Ayllón, similar to what has been shown for the broader Mediterranean region $[4,116,117]$. Likewise, in accordance to previous studies [2,13,32-36], we found evidence that burned area influenced (positive or negative) LULC. This was likely a two-directional relation, because we also found that each LULC category burned differently, and that mosaics composed of more patches of agriculture (in Estrela), and agriculture and pastures (in Ayllón), were less likely to burn as has been suggested for other areas because fuel is not continuous [37-40].

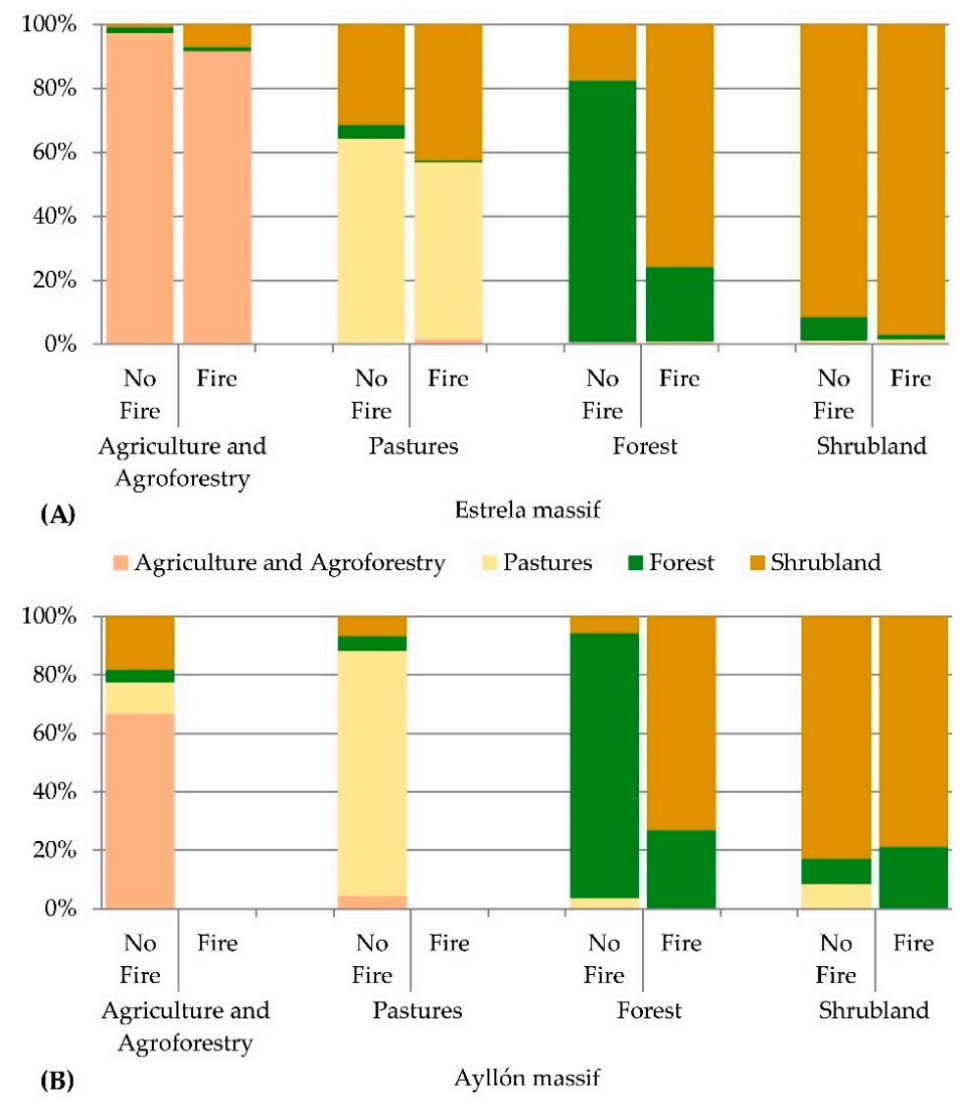

Figure 6. LULC transitions in areas with and without fire in 1990-2012 (weighted average of burned area for the 1990-2000, 2000-2006, and 2006-2012 periods), in the Estrela massif (A) and in the Ayllón massif (B). 


\subsection{Forest Composition Changed through Time, and Fire and Forest Composition Are Related}

FC distribution over time varied between the two ends of the Central Mountain System. In the Estrela massif, most forests were dominated by Pinus, while in the Ayllón massif forests were dominated by Pinus and Quercus (Figure 7). Our results showed that as forest area decreased until 2005 in the Estrela massif, there was less Pinus and more Quercus and Other broadleaved, namely, Eucalyptus (Figure 7A). The large reforestation in the Estrela massif that started in the first decades of the 20th century used Pinus pinaster as the main species [118]. Later, around 1989, stands started being replaced by other Pinus species, Quercus, Castanea, Fagus and other tree species [94], but Pinus stands remained dominant over most of the forest area. As discussed in the above section, from 1990 there was in Estrela a decrease in the fire selectivity of forest, which may be connected with the change in forest composition. The FC in the Estrela massif has two kinds of stands that are in opposite sides of fire proneness: Pinus forests, which are very prone to change due to fire; and, Quercus stands, which are characterized by lower flammability [55,119]. Pinus dominated most of the forest area in the Estrela massif in all times, but the decrease in conifers and increase in broadleaved may have been one of the triggers to reduce fire selectivity of forest LULC category. Although this assumption seems coherent with the literature [23,37], we cannot confirm it because the format of the forest composition data in Estrela (grid points) does not allow overlapping FC and burned areas.
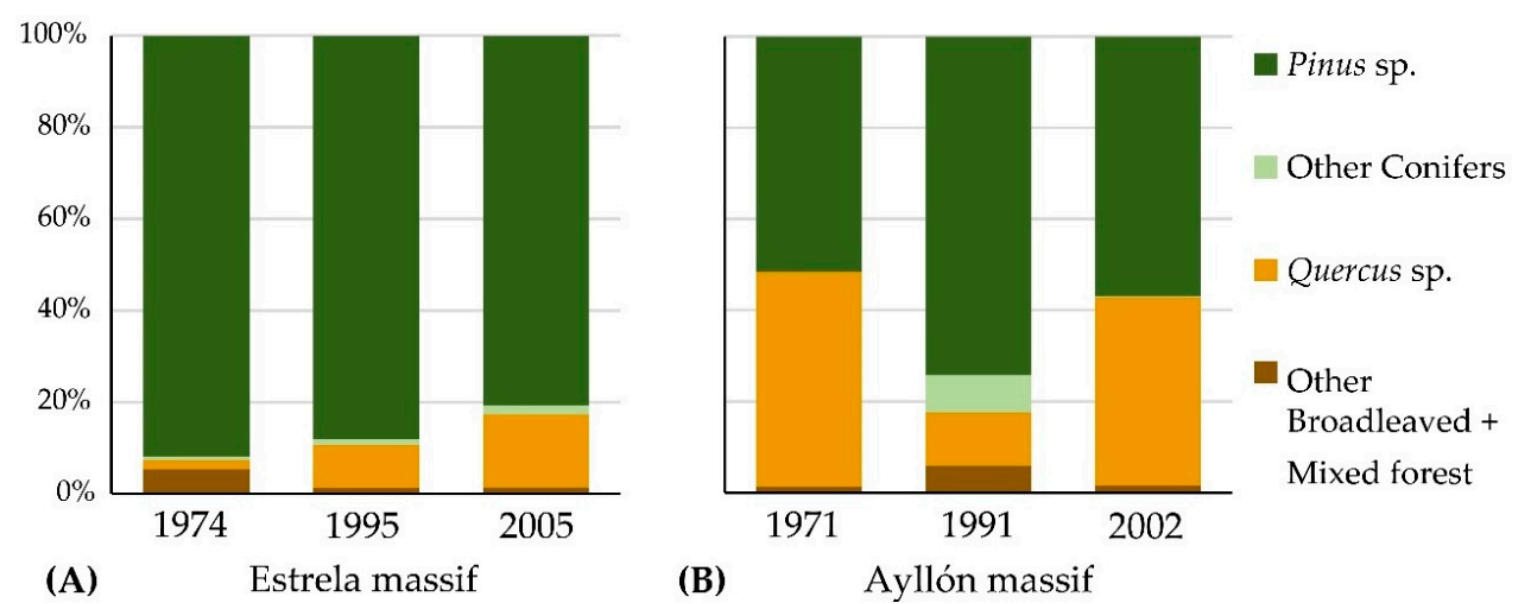

Figure 7. Forest composition (percent of total land area) in the Estrela massif (A) and in the Ayllón massif (B).

In Ayllón, FC changed between 1971 and 2002. For the 1971-1991 perios, Pinus increased, but in the following period, FC almost returned to its original composition (Figure 7B). Here the reforestation was carried out mainly with Pinus sylvestris, Pinus pinaster and Pinus nigra in continuous and solid mono-specific stands, and at the same time, fire was forbidden as a management tool [120]. These new stands started competing with the prior Quercus stands that were very well adapted to the site and in some places the reforestation was not successful. Reforestation resulted in simple stand structure and homogeneity was enhanced, which increased the wildfire risk [52,121-123].

When we analyzed fire selectivity in the Ayllón massif in the two wider classes of FC (Broadleaved + Mixed forest and Conifers), our results showed that between 1971 and 1991, conifers was the only forest category selected by fire and its index was high (2.20) (Figure 8A). Nevertheless, it is curious that in 1971 nearly half of the total area was broadleaved (Quercus) and this category was not selected at all by fire (Figure 7B), but this result is consistent with the literature that refers to the higher flammability of conifers compared to broadleaved or mixed forests [20,124,125]. After that, for the 1991-2002 period, which coincides with the higher selectivity index for forest compared to other LULC categories (Figure 5B), both conifers and broadleaved + mixed forest were equally selected by fire. Likely because fires in this period were larger (see maximum fire size in Figure 4B), the selectivity of 
fire decreased $[23,37]$. Concerning the FC changes, fire decreased broadleaved stands and increased conifers and shrubland areas in original areas of broadleaved between 1971 and 2002 (Figure 8B). In the original areas of conifers, fire promoted an increase in conifers compared with the no fire situation for the 1971-1991 period. After 1991, fire promoted transitions to other categories other than forest. The fact that until 2002, according to our results, conifers changed much less than broadleaved may suggest that conifers were more fire-adapted and more resilient in Ayllón than broadleaved, which is also in accordance with literature [110].

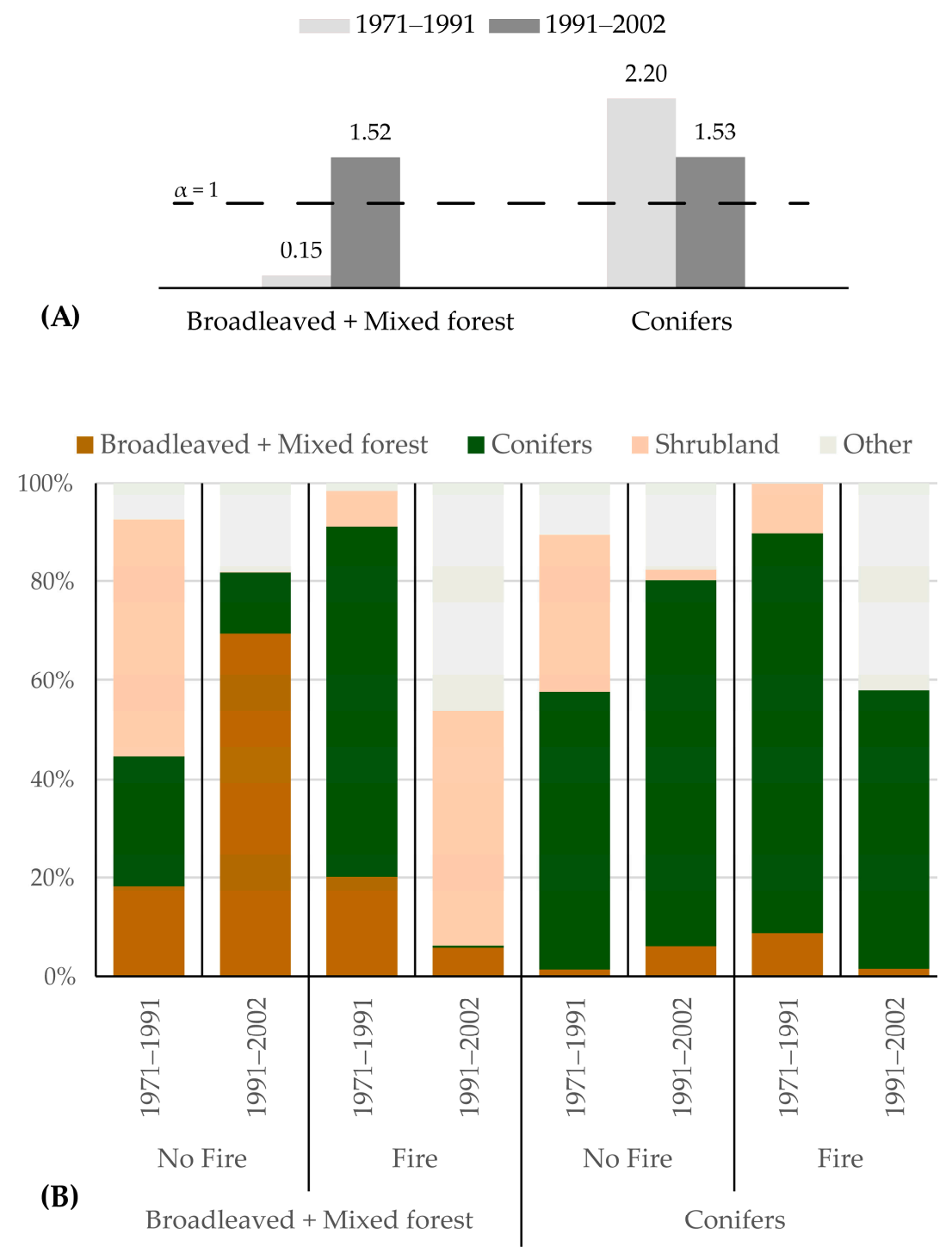

Figure 8. Fire selectivity index in the Ayllón massif, based on Manly's index [76] (A) and Forest composition transitions in areas with and without fire in the Ayllón massif for the 1971-1991 and 1991-2002 periods (B). Here, we joined Quercus sp. plus Other Broadleaved + Mixed forest in one bigger class named "Broadleaved + Mixed forest", and we joined Pinus sp. plus Other conifers in another bigger class named "Conifers".

Overall, our results were in accordance with other studies that focused on LULC changes and fire in the mountainous areas of the Mediterranean Basin, especially in the Iberian Peninsula (e.g., [13]). Others highlighted the outcomes of the processes of human population decline in rural areas; coercive reforestations carried out above all in common lands, municipal lands, and pasturelands; change of the markets demands after entering the EU; and land abandonment. Fire was important in both massifs and the changes in landscape are associated with different drivers of fire in different time periods as 
suggested by Viedma et al. for another massif within the Central Mountain System [52]. Changes in the traditional rural system and the development of the tertiary sector of the economy, including the tourism requirements, have likely played a major role in the contrasting fire regimes in these two massifs. The increased area of shrubland in Estrela, and its decrease in Ayllón, associated with a higher fire frequency and larger fires, may indicate that fires likely have contributed to a less resilient forest in the Estrela massif when compared to the Ayllón massif [13]. While the new rural system in Ayllón is still somehow connected with the old traditional activities (livestock grazing), in Estrela the more developed area belongs to the tertiary sector, which is far from the old traditional activities. This highlights how two areas belonging to the same region and subjected to successive changes imposed by their socioeconomic exterior context (national and European) had developed differently.

\subsection{Value, Limitations and Future Research}

LULC influenced and was influenced by fire in Estrela and in Ayllón. Knowing that there is a striking difference in fire frequency in both massifs, we focused on the burned area and we found that LULC changes are likely strongly related to fire, and both were influenced by national and European policies (e.g., reforestations and becoming members of the European Union). The two massifs had similar relationships between vegetation and fire, but the relative importance of LULC and fire reflected the different social contexts as well as the long-term history of differing land uses in the two case study areas. Despite not addressing climate, which likely influenced both fire and LULC, this recent historical perspective and comparative case study approach was useful for making inferences about fire and landscape change based on empirical, descriptive data and therefore elucidating complex relationships [126]. We cannot attribute cause and effect based on this descriptive and empirical analysis, but the similarities within these case studies and broader regional and national studies lends credibility to our conclusions (e.g., [13,27]). Unfortunately, we cannot further investigate the current forest composition dynamics, because the latest NFI data have not been updated recently. Future research needs a closer perspective to understand the local social influences on fires and landscapes. Our work can inform fire and ecosystem management in the Iberian Peninsula, which is valuable considering that there is still a lack of coordination of fire policies across the Portuguese and Spanish borders $[127,128]$. In particular, the understanding of the interconnections between fire regimes and landscape changes can inform fire managers on the likely effects of altering fire regimes on the landscape and inform landscape planners on the likely effect of altering landscapes on the fire regimes. The local impacts of different historical fire management policies, historical land management policies and historical protection guidelines, as well as the phenomena of the rural exodus and land abandonment in each of these two inner mountain areas are definitely worth to explore in order to better understand the disparity of fire occurrence in these two case study areas $[14,49,89,128,129]$.

\section{Conclusions}

In the Central Mountain System, there has been a dynamic and close interaction between LULC and fire since the second half of the 20th century. Using a landscape scale of empirical analysis, we were able to validate our initial hypotheses. We found that (1) fire likely affected LULC transitions and that (2) LULC influenced fire selectivity as different LULC categories had different fire proneness in both the Estrela and Ayllón massifs. There was a close resemblance in both case study areas in what concerns the overall influence of fire in the LULC transitional processes, but pasture areas differed (less prone to change to other categories, and more prone to transition from other categories in Ayllón than in Estrela), highlighting the different social-ecological systems of the two case study areas. Future work should further explore other forces driving current and historical fire frequency, particularly the climate and the social factors that will likely explain the differences found for two areas with regional and biophysical similarities. Our results suggest that LULC dynamics and fire are mostly affected by local scale disturbances, and that both can be influenced by regional and national policies. Given these 
multiple interactions, careful planning and conscious fire management are important for obtaining local results.

Supplementary Materials: The following are available online at http://www.mdpi.com/2571-6255/2/3/45/s1. Table S1. CORINE land cover (CLC) categories and nomenclature, and our reclassification of the CLC into the six LULC new classes; Table S2. National Forest Inventories (NFI) nomenclatures and reclassification of the NFIs into the five Forest composition (FC) categories we analyzed; Figure S1. Comparison of National fire databases (fire records) with European Forest Fire database (EFFIS) (a satellite image-based database) in 2000-2011; Figure S2. Methodology flowchart.

Author Contributions: Conceptualization: F.C.R., C.M.-M. and C.R.S.; Formal analysis: C.R.S., F.C.R. and C.M.-M.; Funding acquisition: C.M.-M.; Investigation: C.R.S.; Methodology: C.M.-M., F.C.R. and C.R.S.; Project administration: C.M.-M.; Supervision: F.C.R., C.M.-M. and P.M.; Writing of original: C.R.S.; Review and editing: C.M.-M. and P.M.

Funding: This research was funded by the Spanish Science Ministry (grant number BES-2014-068696), and by the Spanish Ministry of Economy and Competitiveness (National Research Projects Program), grant numbers CSO2013-44144-P and CSO2017-87614-P.

Acknowledgments: We thank the Spanish Ministry of Agriculture and the Government of Castilla-La Mancha for the forest fire databases provided. We are grateful to L. Vilar, the four anonymous reviewers and the review editor for their constructive comments on earlier versions of the manuscript.

Conflicts of Interest: The authors declare no conflict of interest.

\section{References}

1. Fernández, D.; Corbelle, E. Cambios en los usos de suelo en la Península Ibérica: Un meta-análisis para el período 1985-2015. Rev. Bibliográfica Geogr. Ciencias Soc. 2017, 21, 215.

2. Moreira, F.; Viedma, O.; Arianoutsou, M.; Curt, T.; Koutsias, N.; Rigolot, E.; Barbati, A.; Corona, P.; Vaz, P.; Xanthopoulos, G.; et al. Landscape-wildfire interactions in southern Europe: Implications for landscape management. J. Environ. Manag. 2011, 92, 2389-2402. [CrossRef] [PubMed]

3. Rego, F.C. Land use changes and wildfires. In Responses of Forest Ecosystems to Environmental Changes; Teller, A., Mathy, P., Jeffers, J.N.R., Eds.; Springer: Dordrecht, The Netherlands; Luxembourg, 1992; pp. 367-368. ISBN 978-94-011-2866-7.

4. Silva, J.S.; Vaz, P.; Moreira, F.; Catry, F.; Rego, F.C. Wildfires as a major driver of landscape dynamics in three fire-prone areas of Portugal. Landsc. Urban Plan. 2011, 101, 349-358. [CrossRef]

5. Meneses, B.; Reis, E.; Pereira, S.S.; Vale, M.J. Understanding driving forces and implications associated with the land use and land cover changes in portugal. Sustainability 2017, 9, 351. [CrossRef]

6. Plieninger, T.; Draux, H.; Fagerholm, N.; Bieling, C.; Bürgi, M.; Kizos, T.; Kuemmerle, T.; Primdahl, J.; Verburg, P.H. The driving forces of landscape change in Europe: A systematic review of the evidence. Land Use Policy 2016, 57, 204-214. [CrossRef]

7. Vilar, L.; Camia, A.; San-Miguel-Ayanz, J.; Martín, M.P. Modeling temporal changes in human-caused wildfires in Mediterranean Europe based on land use-land cover interfaces. For. Ecol. Manag. 2016, 378, 68-78. [CrossRef]

8. Paniagua, A.; Hoggart, K. The restructuring of rural Spain? J. Rural Stud. 2001, 17, 63-80.

9. Viedma, O.; Moity, N.; Moreno, J.M. Changes in landscape fire-hazard during the second half of the 20th century: Agriculture abandonment and the changing role of driving factors. Agric. Ecosyst. Environ. 2015, 207, 126-140. [CrossRef]

10. Montiel-Molina, C. Presencia Histórica Del Fuego En El Territorio; Ministerio de Agricultura y Pesca Alimentación y Medio Ambiente (MAPAMA): Madrid, Spain, 2013; ISBN 978-84-491-1289-8.

11. García Novo, F.; Casal, M.; Pausas, J.G. Ecología De La Regeneración De Zonas Incendiadas; Academia de Ciencias Sociales y del Medio Ambiente de Andalucía: Sevilla, Spain, 2018; ISBN 978-84-09-05946-1.

12. Gallardo, M.; Gómez, I.; Vilar, L.; Martínez-Vega, J.; Martín, M.P. Impacts of future land use/land cover on wildfire occurrence in the Madrid region (Spain). Reg. Environ. Chang. 2016, 16, 1047-1061. [CrossRef]

13. Viedma, O.; Moreno, J.M.; Rieiro, I. Interactions between land use/land cover change, forest fires and landscape structure in Sierra de Gredos (Central Spain). Environ. Conserv. 2006, 33, 212-222. [CrossRef]

14. Nunes, A.; Lourenço, L.; Meira, A.C. Exploring spatial patterns and drivers of forest fires in Portugal (1980-2014). Sci. Total Environ. 2016, 573, 1190-1202. [CrossRef] [PubMed] 
15. Martínez de Pisón, E.; Molina Holgado, P. Diversidad del paisaje natural. In La Diversidad Biológica De España; Pineda, F.D., Ed.; Prentice Hall: Madrid, Spain, 2002; pp. 33-44. ISBN 9788420535159.

16. Janssen, C.R.; Woldringh, R.E. A preliminary radiocarbon dated pollen sequence from the Serra da Estrela, Portugal. Finisterra 1981, 16, 299-309. [CrossRef]

17. Ribeiro, C.; Delgado, J.N. Relatório Acerca Da Arborisação Geral Do Paíz Apresentada A Sua Excellencia O Ministro Das Obras Publicas, Commercio E Industria Em Resposta Aos Quesitos do Artigo 1o Do Decreto De 24 de Setembro de 1867; Typographia da Academia Real das Sciencias: Lisboa, Portugal, 1868.

18. Caetano, M.; Marcelino, F. CORINE Land Cover de Portugal Continental 1990-2000-2006-2012-Relatório Tecnico; Direção-Geral do Território (DGT): Lisboa, Portugal, 2017.

19. Watson, R.T.; Noble, I.R.; Bolib, B.; Ravindranath, N.H.; Verardo, D.J.; Dokken, D.J. Land Use, Land-Use Change and Forestry: A Special Report of the Intergovernmental Panel on Climate Change 2000; Cambridge University Press: London, UK, 2000.

20. Silva, J.; Moreira, F.; Vaz, P.; Catry, F.; Ferreira, P. Assessing the relative fire proneness of different forest types in Portugal. Plant Biosyst. 2009, 143, 597-608. [CrossRef]

21. Meneses, B.; Reis, E.; Reis, R. Assessment of the recurrence interval of wildfires in mainland Portugal and affected LUC patterns identification. J. Maps 2018, 14, 282-292. [CrossRef]

22. Marques, S.; Borges, J.G.; Garcia-Gonzalo, J.; Moreira, F. Characterization of wildfires in Portugal. Eur. J. For. Res. 2011, 130, 775-784. [CrossRef]

23. Nunes, M.C.S.; Vasconcelos, M.J.; Pereira, J.M.C.; Dasgupta, N.; Alldredge, R.J.; Rego, F.C. Land cover type and fire in Portugal: Do fires burn land cover selectively? Landsc. Ecol. 2005, 20, 661-673. [CrossRef]

24. Postigo-Mijarra, J.M.; Génova, M.; Gómez-Manzaneque, F.; Martínez-García, F.; Morla, C.; Vegas, J.; Perucha, M.Á. Occurrence of continuous Holocene pinewoods (Pinus sylvestris L.) in the Eastern Central System (Spain) inferred from macroremains. New data from the Sandria site. Rev. Palaeobot. Palynol. 2017, 246, 70-84. [CrossRef]

25. Franco Múgica, F.; García Antón, M.; Maldonado Ruiz, J.; Morla Juaristi, C.; Sainz Ollero, H. Evolución de la vegetación en el sector septentrional del macizo de Ayllón (Sistema Central). Análisis polínico de la turbera de Pelagallinas. An. del Jardín Botánico Madri 2001, 59, 113-124.

26. Gómez de Mendoza, J.; Mata, R. Actuaciones forestales públicas desde 1940. Objetivos, criterios y resultados. Agric. Soc. 1992, 65, 15-64.

27. Montiel-Molina, C.; Karlsson-Martín, O.; Galiana-Martín, L. Regional fire scenarios in Spain: Linking landscape dynamics and fire regime for wildfire risk management. J. Environ. Manag. 2018, 233, 427-439. [CrossRef]

28. Moreno, M.V.; Conedera, M.; Chuvieco, E.; Pezzatti, G.B. Fire regime changes and major driving forces in Spain from 1968 to 2010. Environ. Sci. Policy 2014, 37, 11-22. [CrossRef]

29. Pausas, J.G.; Fernández-Muñoz, S. Fire regime changes in the Western Mediterranean Basin: From fuel-limited to drought-driven fire regime. Clim. Chang. 2012, 110, 215-226. [CrossRef]

30. Silva, J.M.N.; Moreno, M.V.; Le Page, Y.; Oom, D.; Bistinas, I.; Pereira, J.M.C. Spatiotemporal trends of area burnt in the Iberian Peninsula, 1975-2013. Reg. Environ. Chang. 2018. [CrossRef]

31. Jiménez-Ruano, A.; Rodrigues Mimbrero, M.; De La Riva Fernández, J. Exploring spatial-temporal dynamics of fire regime features in mainland Spain. Nat. Hazards Earth Syst. Sci. 2017, 17, 1697-1711. [CrossRef]

32. Pausas, J.G. Simulating Mediterranean landscape pattern and vegetation dynamics under different fire regimes. Plant Ecol. 2006, 187, 249-259. [CrossRef]

33. Fernandes, P.; Luz, A.; Loureiro, C.; Ferreira-Godinho, P.; Botelho, H. Fuel modelling and fire hazard assessment based on data from the Portuguese National Forest Inventory. For. Ecol. Manag. 2006, 234, S229. [CrossRef]

34. Nunes, A.N. Regional variability and driving forces behind forest fires in Portugal an overview of the last three decades (1980-2009). Appl. Geogr. 2012, 34, 576-586. [CrossRef]

35. Martínez-Fernandéz, J.; Vega-garcía, C.; Chuvieco, E. Human-caused wildfire risk rating for prevention planning in Spain. J. Environ. Manag. 2008, 90, 1241-1252. [CrossRef]

36. Rego, F.; Louro, G.; Constantino, L. The impact of changing wildfire regimes on wood availability from Portuguese forests. For. Policy Econ. 2013, 29, 56-61. [CrossRef]

37. Barros, A.M.G.; Pereira, J.M.C. Wildfire selectivity for land cover type: Does size matter? PLoS ONE 2014, 9, e84760. [CrossRef] 
38. Moreira, F.; Vaz, P.; Catry, F.; Silva, J.S. Regional variations in wildfire susceptibility of land-cover types in Portugal: Implications for landscape management to minimize fire hazard. Int. J. Wildland Fire 2009, 18, 563-574. [CrossRef]

39. Sebastián-López, A.; Salvador-Civil, R.; Gonzalo-Jiménez, J.; SanMiguel-Ayanz, J. Integration of socio-economic and environmental variables for modelling long-term fire danger in Southern Europe. Eur. J. For. Res. 2008, 127, 149-163. [CrossRef]

40. Moreno, J.M.; Viedma, O.; Zavala, G.; Luna, B. Landscape variables influencing forest fires in central Spain. Int. J. Wildland Fire 2011, 20, 678-689. [CrossRef]

41. Verdú, F.; Salas, J.; Vega-García, C. A multivariate analysis of biophysical factors and forest fires in Spain, 1991-2005. Int. J. Wildland Fire 2012, 21, 498. [CrossRef]

42. Martínez-Fernández, J.; Chuvieco, E.; Koutsias, N. Modelling long-term fire occurrence factors in Spain by accounting for local variations with geographically weighted regression. Nat. Hazards Earth Syst. Sci. 2013, 13, 311-327. [CrossRef]

43. Moreira, F.; Catry, F.X.; Rego, F.; Bacao, F. Size-dependent pattern of wildfire ignitions in Portugal: When do ignitions turn into big fires? Landsc. Ecol. 2010, 25, 1405-1417. [CrossRef]

44. Catry, F.X.; Rego, F.; Bação, F.; Moreira, F. Modeling and mapping wildfire ignition risk in Portugal. Int. J. Wildland Fire 2009, 18, 921-931. [CrossRef]

45. Koutsias, N.; Martínez-Fernández, J.; Allgöwer, B. Do factors causing wildfires vary in space? Evidence from geographically weighted regression. GISci. Remote Sens. 2010, 47, 221-240. [CrossRef]

46. Oliveira, S.; Oehler, F.; San-Miguel-Ayanz, J.; Camia, A.; Pereira, J.M.C. Modeling spatial patterns of fire occurrence in Mediterranean Europe using Multiple Regression and Random Forest. For. Ecol. Manag. 2012, 275, 117-129. [CrossRef]

47. Carmo, M.; Moreira, F.; Casimiro, P.; Vaz, P. Land use and topography influences on wildfire occurrence in northern Portugal. Landsc. Urban Plan. 2011, 100, 169-176. [CrossRef]

48. Moreira, F.; Rego, F.C.; Ferreira, P.G. Temporal (1958-1995) pattern of change in a cultural landscape of northwestern Portugal: Implications for fire occurrence. Landsc. Ecol. 2001, 16, 557-567. [CrossRef]

49. Beilin, R.; Reid, K. It's not a 'thing' but a 'place': Reconceptualising 'assets' in the context of fire risk landscapes. Int. J. Wildland Fire 2015, 24, 130-137. [CrossRef]

50. Wilbanks, T.J.; Kates, R.W. Global change in local places: How scale matters. Clim. Chang. 1999, 43, 601-628. [CrossRef]

51. Turner II, B.; Meyer, W.B.; Skole, D.L. Global land-use/land-cover change: Towards an integrated study. Integr. Earth Syst. Sci. 1994, 23, 91-95.

52. Viedma, O.; Urbieta, I.R.; Moreno, J.M. Wildfires and the role of their drivers are changing over time in a large rural area of west-central Spain. Sci. Rep. 2018, 8, 1-13. [CrossRef] [PubMed]

53. Acácio, V.; Holmgren, M.; Rego, F.; Moreira, F.; Mohren, G.M.J. Are drought and wildfires turning Mediterranean cork oak forests into persistent shrublands? Agrofor. Syst. 2009, 76, 389-400. [CrossRef]

54. Oliveira, T.M.; Guiomar, N.; Baptista, F.O.; Pereira, J.M.C.; Claro, J. Is Portugal's forest transition going up in smoke? Land Use Policy 2017, 66, 214-226. [CrossRef]

55. Silva, J.S.; Vaz, P.; Moreira, F.; Catry, F.; Rego, F. Assessing fire-driven land use dynamics in Portugal. In Proceedings of the VI International Conference on Forest Fire Research, Coimbra, Portugai, 15-18 November 2010.

56. De Vicente, G. La extraña topografía de la Península Ibérica. Enseñanzas la Ciencias la Tierra 2007, 15, $124-134$.

57. Aparicio, A.; Garcia Cacho, L. Geologia del Sistema Central Español; Consejeria de Politica Territorial-Consejo Superior de Investigaciones Cientificas: Comunidad de Madrid, Madrid, Spain, 1987; ISBN 84-451-0024-6.

58. Capel Molina, J.J. El clima de la Peninsula Ibérica; Colección; Ariel: Barcelona, Spain, 2000; ISBN 9788434434660.

59. FAO. FAO Climate Database; FAO: Rome, Italy, 1961-2015.

60. AEMET-IM. Atlas climático ibérico/Iberian climate atlas; Agencia Estatal de Meteorología, Ministerio de Medio Ambiente y Medio Rural y Marino: Madrid, Spain, 2011; ISBN 9788478370795.

61. INE-Statistics Portugal Population Census (Year: from 1864 to 2001, Variable: Number of inhabitants, Scale: Municipality). Available online: https://www.ine.pt (accessed on 6 February 2019).

62. INE-Statistics Spain Population Census (Year: from 1877 to 2001, Variable: Number of inhabitants, Scale: Municipality). Available online: https://www.ine.es (accessed on 6 February 2019). 
63. Afonso, M.J.; Marques, J.E.; Marques, J.M.; Carreira, P.; Carvalho, J.M.; Silva, M.M.; Samper, J.; Pisani, B.; Borges, F.; Rocha, F.; et al. Hydrogeology of hard-rocks in the Portuguese Iberian Massif: Porto urban area and Serra da Estrela mountain region. In Proceedings of the The Fourth Inter-Celtic Colloquium on Hydrology and Management of Water Resources, Universidade do Minho, Guimarães, Portugal, 11-13 July 2005; pp. 1-12.

64. Brum Ferreira, A.; Alcoforado, M.J.; Vieira, G.T.; Mora, C.; Jansen, J. Metodologias de análise e de classificação das paisagens. O exemplo do projecto Estrela. Finisterra 2001, 36, 157-178. [CrossRef]

65. Fidalgo, C. La Transformación Humana del Paisaje en la Serranía de Atienza; Ediciones de la Universidad Autónoma de Madrid: Madrid, Spain, 1987.

66. Gómez, A.L. La Serranía de Atienza (Estudio de Geografia Humana). Ph.D. Thesis, Facultad de Filosofía y Letras, Universidad de Madrid, Madrid, Spain, 1951.

67. Fernández-Muñoz, S. Consecuencias socioeconómicas y territoriales de las repoblaciones forestales en el Alto Sorbe (Guadalajara). Eria 2002, 58, 183-203.

68. Caetano, M.; Carrão, H.; Painho, M. Alterações da ocupação do solo em Portugal Continental: 1985-2000; Instituto do Ambiente: Lisboa, Portugal, 2005; ISBN 9728577222.

69. Almeida, A.C.; Nunes, A.; Figueiredo, A. Mudanças no uso do solo no interior Centro e Norte de Portugal; Imprensa da Universidade de Coimbra: Coimbra, Portugai, 2009; ISBN 978-972-8074-96-6.

70. Meneses, B.; Vale, M.J. Modelling land use and land cover changes in Portugal: A multi-scale and multi-temporal approach. Finisterra 2018, 107, 3-26. [CrossRef]

71. Tomppo, E.; Gschwantner, T.; Lawrence, M.; McRoberts, R.E. National Forest Inventories: Pathways for Common Reporting; Springer Science + Business Media, B.V.: Dordrecht, The Netherlands, 2010; ISBN 9789048132324.

72. Direcção Nacional de Gestão Florestal. Inventário Florestal Nacional Portugal Continental-IFN5 2005 2006; Autoridade Florestal Nacional, Ed.; Autoridade Florestal Nacional: Lisboa, Portugal, 2010; ISBN 9789728097769.

73. UNAP-JCCM Unidad de Análisis y Planificación del Centro Operativo Regional Para la Lucha Contra Incendios Forestales, Junta de Castilha-La Mancha. Personal communication, 2016.

74. San-Miguel-Ayanz, J.; Schulte, E.; Schmuck, G.; Camia, A.; Strobl, P.; Liberta, G.; Giovando, C.; Boca, R.; Sedano, F.; Kempeneers, P.; et al. COMPREHENSIVE monitoring of Wildfires in Europe: The European Forest Fire Information System (EFFIS); European Commission: Brussels, Belgium, 2012; pp. 87-108.

75. Balzter, H. Markov chain models for vegetation dynamics. Ecol. Model. 2000, 126, 139-154. [CrossRef]

76. Rego, F.C.; Bunting, S.C.; Strand, E.K.; Godinho Ferreira, P. Applied Landscape Ecology; John Wiley and Sons Ltd.: Hoboken, NJ, USA, 2019; ISBN 9781119368243.

77. Serviço de Inventário Florestal e Cartografia. Distribuição da Floresta em Portugal Continental-Áreas florestais por Concelhos 1980; Ministério da Agricultura e Pescas, Secretaria de Estado do Fomento Agrário- Direcção-Geral de Ordenamento e Gestão Florestal: Lisboa, Portugal, 1981.

78. Marques, P.P. Serra da Estrela: Gestão e Conservação de Habitats Prioritários-Projecto LIFE Natureza (LIFE02/NAT/P/8478); Associação de Produtores Florestais do Paul: Tortosendo, Portugal, 2006.

79. Bordiú Barreda, E. Valoración de la infrautilización de la Sierra de Ayllón y aportación de un modelo alternativo. An. Geogr. la Univ. Complut. 1985, 167-187.

80. Baptista, F.O. O Espaço Rural-Declínio da Agricultura, 1st ed.; Celta: Lisboa, Portugal, 2010; ISBN 978-972-774-269-1.

81. Cabral, M.V. Agrarian structures and recent rural movements in Portugal. J. Peasant Stud. 1978, 5, 411-445. [CrossRef]

82. Amaral, L. Portugal e o passado: Política agrária, grupos de pressão e evolução da agricultura portuguesa durante o Estado Novo. Análise Soc. 1994, XXIX, 889-906.

83. Engerman, S.; das Neves, J. The bricks of an empire 1415-1999: 585 years of Portuguese emigration. J. Eur. Econ. Hist. 1997, 26, 471-510.

84. Martinho, A.T. O Pastoreio e o Queijo da Serra, SNPRPP, ed.; 2a edição.; Serviço Nacional de Parques Reservas e Património Paisagístico: Lisboa, Portugal, 1981.

85. INE-Statistics Spain Spanish Census of Agriculture (Year: 1989 and 1999, Variable: Cattle units, Scale: Municipality). Available online: https://www.ine.es (accessed on 6 February 2019). 
86. Dirección General de Política Forestal y Espacios Naturales; Junta de Comunidades de Castilla-La Mancha. Plan de Gestión de Sierra de Ayllón, ES0000164/ES0000488 (Guadalajara)-Diagnóstico del espacio Natura 2000; Dirección General de Política Forestal y Espacios Naturales: Guadalajara, Spain, 2017.

87. Mateus, A. A economia portuguesa depois da adesão às Comunidades Europeias: Transformações e desafios. Análise Soc. 1992, XXVIII, 655-671.

88. Plaza Gutiérrez, J.I.; Martín Jiménez, M.I.; Hortelano Mínguez, L.A.; Fernández Álvarez, R. Desarrollo territorial y cambios en las montañas interiores (factores, tendencias e iniciativas). Contrastes y estudios de caso. Polígonos. Rev. Geogr. 2008, 18, 155-191. [CrossRef]

89. Mazzoleni, S.; di Pasquale, G.; Mulligan, M.; di Martino, P.; Rego, F. Recent Dynamics of the Mediterranean Vegetation and Landscape; John Wiley \& Sons Ltd.: Chichester, UK, 2004; ISBN 9780470093719.

90. Feranec, J.; Soukup, T.; Hazeu, G.; Jaffrain, G. European Landscape Dynamics-Corine Land Cover Data; CRC Press-Taylor\&Francis Group: Boca Rton, FL, USA, 2016; ISBN 9781482244663.

91. Feranec, J.; Jaffrain, G.; Soukup, T.; Hazeu, G. Determining changes and flows in European landscapes 1990-2000 using CORINE land cover data. Appl. Geogr. 2010, 30, 19-35. [CrossRef]

92. Bunting, S.C.; Rego, F.C. Human impact on Portugal's vegetation. Rangelands 1988, 10, 251-255.

93. Fernández Muñoz, S.; Mata Olmo, R. Pasado y presente de las repoblaciones forestales en montes de sociedades de vecinos. Estud. Geográficos 2000, LXI, 461-486.

94. Barjona de Freitas, A.S. Perímetro Florestal De Manteigas; Direcção Geral Das Florestas, Ed.; Seleprinter, Lda.: Lisboa, Portugal, 1989.

95. Jones, N.; de Graaff, J.; Rodrigo, I.; Duarte, F. Historical review of land use changes in Portugal (before and after EU integration in 1986) and their implications for land degradation and conservation, with a focus on Centro and Alentejo regions. Appl. Geogr. 2011, 31, 1036-1048. [CrossRef]

96. Diogo, V.; Koomen, E. Explaining land-use change in Portugal 1990-2000. In Proceedings of the 13th AGILE International Conference on Geographic Information Science, Guimarães, Portugal, 11-14 May 2010; p. 11.

97. Jucker Riva, M.; Daliakopoulos, I.N.; Eckert, S.; Hodel, E.; Liniger, H. Assessment of land degradation in Mediterranean forests and grazing lands using a landscape unit approach and the normalized difference vegetation index. Appl. Geogr. 2017, 86, 8-21. [CrossRef]

98. Rudel, T.K.; Coomes, O.T.; Moran, E.; Achard, F.; Angelsen, A.; Xu, J.; Lambin, E. Forest transitions: Towards a global understanding of land use change. Glob. Environ. Chang. 2005, 15, 23-31. [CrossRef]

99. Delgado Viñas, C. Agrarian dynamics and landscape in rural mountain areas of Spain. J. Settl. Spat. Plan. 2015, 145-154.

100. Lourenço, L.; Fernandes, S.; Nunes, A.; Gonçalves, A.B.; Vieira, A. Determination of forest fire causes in Portugal (1996-2010). Flamma 2013, 4, 171-175.

101. Porrero Rodríguez, M.A. Incendios forestales-investigación de causas; Mundiprensa: Madrid, Spain, 2001; ISBN 9788471149541.

102. Nunes, A.; Lourenço, L.; Fernandes, S.; Castro, A.C.M. Principais causas dos incêndios florestais em Portugal: Variaçao espacial no período 2001/12. Territorium 2014, 21, 135-146. [CrossRef]

103. Vélez Muñoz, R. Incendios forestales y su relación con el medio rural. Rev. Estud. Agro-sociales 1986, 136, 195-224.

104. González Márquez, J. Climatología de tormentas en España-years 1997 to 2006; Meteored: Madrid, Spain, 2006.

105. Acebrón, M.L.G. Tipificación de los incendios forestales en la provincia de Guadalajara (Castilla-La Mancha). For.-Asoc. y Col. Of. Ing. Técnicos For. 2017, 67, 32-39.

106. Pausas, J.G.; Vallejo, V.R. The role of fire in European Mediterranean Ecosystems. In Remote Sensing of Large Wildfires in the European Mediterranean Basin; Chuvieco, E., Ed.; Springer: Berlin/Heidelberg, Germany, 1999; pp. 3-16, ISBN 978-3-642-64284-5.

107. Oliveira, S.; Moreira, F.; Boca, R.; San-Miguel-Ayanz, J.; Pereira, J.M.C. Assessment of fire selectivity in relation to land cover and topography: A comparison between Southern European countries. Int. J. Wildland Fire 2014, 23, 620-630. [CrossRef]

108. INE-Statistics Portugal Portuguese General Census of Agriculture (Year: 1999 and 2009, Variable: Cattle units, Scale: Municipality). Available online: https://www.ine.pt (accessed on 27 March 2019).

109. INE-Statistics Spain Spanish Census of Agriculture (Year: 1999 and 2009; Variables: Cattle units; Scale: Municipality). Available online: http://www.ine.es (accessed on 27 March 2019). 
110. Fernandes, P.M. Fire-smart management of forest landscapes in the Mediterranean basin under global change. Landsc. Urban Plan. 2013, 110, 175-182. [CrossRef]

111. Prichard, S.J.; Stevens-Rumann, C.S.; Hessburg, P.F. Tamm Review: Shifting global fire regimes: Lessons from reburns and research needs. For. Ecol. Manag. 2017, 396, 217-233. [CrossRef]

112. Castro, M.; Castro, J.; Sal, G.; Quinta, B.; Apolónia, D.S. Efeito da pastorícia tradicional na redução de combustíveis finos em bosques de Quercus pyrenaica. Silva Lusit. 2009, 17, 159-169.

113. Moreira, M.B.; Coelho, I.S. A Silvopastorícia na Prevenção dos Fogos Rurais; ISAPress: Lisbon, Portugal, 2008; ISBN 978-972-8669-32-4.

114. Mather, A.S.; Pereira, J.M.C. Transição florestal e fogo em Portugal. In Incendios Florestais em Portugal; Pereira, J.S., Pereira, J.M.C., Rego, F.C., Silva, J.M., Silva, T.P., Eds.; ISAPress: Lisboa, Portugal, 2006; pp. 257-286.

115. Iriarte-Goñi, I.; Ayuda, M.-I. Should Forest Transition Theory include effects on forest fires? The case of Spain in the second half of the twentieth century. Land Use Policy 2018, 76, 789-797. [CrossRef]

116. Baeza, M.J.; Valdecantos, A.; Alloza, J.A.; Vallejo, V.R. Human disturbance and environmental factors as drivers of long-term post-fire regeneration patterns in Mediterranean forests. J. Veg. Sci. 2009, 18, $243-252$. [CrossRef]

117. Bajocco, S.; Ricotta, C. Evidence of selective burning in Sardinia (Italy): Which land-cover classes do wildfires prefer? Landsc. Ecol. 2008, 23, 241-248. [CrossRef]

118. Devy-Vareta, N. A floresta no espaço e no tempo em Portugal. A arborização da Serra da Cabreira (1919-1975). Ph.D. Thesis, Universidade de Porto, Porto, Portugal, 1993.

119. Gonçalves, A.C.; Sousa, A.M.O. The fire in the Mediterranean Region: A case study of forest fires in Portugal. In Mediterranean Identities-Environment, Society, Culture; Fuerst-Bielis, B., Ed.; IntechOpen: London, UK, 2017; pp. 305-335.

120. Montiel-Molina, C. Comparative assessment of wildland fire legislation and policies in the European Union: Towards a fire framework directive. For. Policy Econ. 2013, 29, 1-6. [CrossRef]

121. Lloret, F.; Calvo, E.; Pons, X.; Díaz-Delgado, R. Wildfires and landscape patterns in the Eastern Iberian Peninsula. Landsc. Ecol. 2002, 17, 745-759. [CrossRef]

122. Lasanta, T. Mountain Mediterranean landscape evolution caused by the abandonment of traditional primary activities: A study of the Spanish Central Pyrenees. Appl. Geogr. 2005, 25, 47-65. [CrossRef]

123. Ioannis, N.; Diofantos, H.; Jacob, K.J.; Hanspeter, L.; Giovanni, Q. How does land management contribute to the resilience of Mediterranean forests and rangelands? A participatory assessment. Land Degrad. Dev. 2018, 29, 10.

124. Pereira, M.G.; Aranha, J.; Amraoui, M. Land cover fire proneness in Europe. For. Syst. 2014, 23, 598-610. [CrossRef]

125. Rego, F.C.; Silva, J.S. Wildfires and landscape dynamics in Portugal: A regional assessment and global implications. In Forest Landscapes and Global Change: Challenges for Research and Management; Azevedo, J.C., Perera, A.H., Pinto, M.A., Eds.; Springer Science+Business Media: New York, NY, USA, 2014; pp. 51-73. ISBN 978-1-4939-0952-0.

126. Rollins, M.; Morgan, P.; Swetnam, T.W. Landscape-scale controls over 20th century fire occurrence in two large Rocky Mountain (USA) wilderness areas. Landsc. Ecol. 2002, 17, 539-557. [CrossRef]

127. Moritz, M.A.; Batllori, E.; Bradstock, R.A.; Gill, A.M.; Handmer, J.; Hessburg, P.F.; Leonard, J.; McCaffrey, S.; Odion, D.C.; Schoennagel, T.; et al. Learning to coexist with wildfire. Nature 2014, 515, 58-66. [CrossRef] [PubMed]

128. Regos, A.; Ninyerola, M.; Moré, G.; Pons, X. Linking land cover dynamics with driving forces in mountain landscape of the Northwestern Iberian Peninsula. Int. J. Appl. Earth Obs. Geoinf. 2015, 38, 1-14. [CrossRef]

129. Paveglio, T.B.; Edgeley, C.M.; Carroll, M.; Billings, M.; Stasiewicz, A.M. Exploring the influence of local social context on strategies for achieving fire adapted communities. Fire 2019, 2, 26. [CrossRef]

(C) 2019 by the authors. Licensee MDPI, Basel, Switzerland. This article is an open access article distributed under the terms and conditions of the Creative Commons Attribution (CC BY) license (http://creativecommons.org/licenses/by/4.0/). 